\title{
أثر نجاح الوساطة على الدعوى المدنية في التشريع الأردني
}

\author{
shel \\ أ.د/ نائل علي المساعدة \\ عضو هيئت التدريس \\ كليتت القانون قسم القانون الخاص

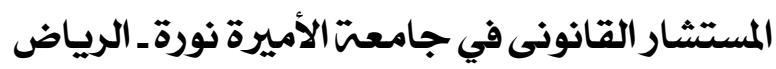 \\ جامعت أل البيت ـ الادرن
}




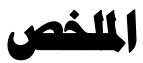

تعتبر الوسـاطة واحدة من انسب الوسـائل البديلـة لتسوية المنازعـات المدنية وذللك بالنظر إلى سماتها الإيجابية العديدة ومن هذه السمات مشاركة الخصوم انفسهم

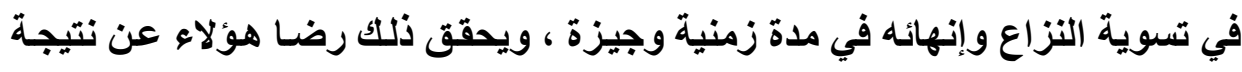

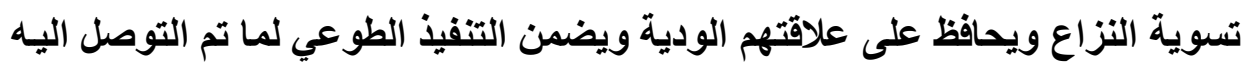

$$
\text { من تسوية. }
$$

وقد تتبه المشرع الاردني مبكرا لأهمية الوسـاطة في تسوية النزاعات المدنية

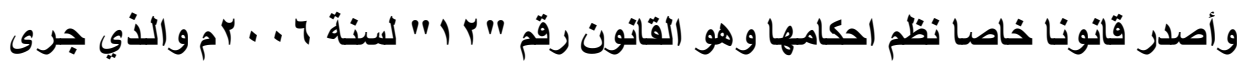

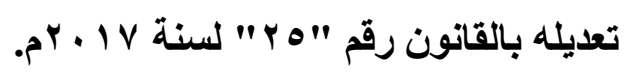
وقد ركزت هذه الاراسة على أهم النتائج التي تترتب على نجاح الوسـاطة في

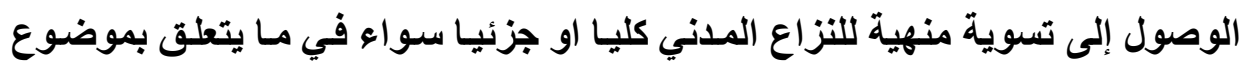

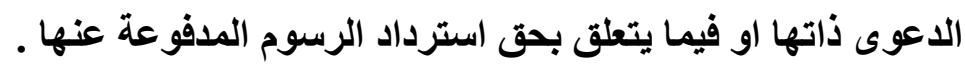
الكلمات المفتاحية: (الدعوى المدنية ، الوساطة ، التسوية ، الحل الودي ) . 


\begin{abstract}
Mediation is one of the most appropriate alternative means of settling civil disputes in view of its many positive features, including the participation of the parties themselves in the settlement and termination of the dispute in a short period of time. This results in their satisfaction with the outcome of the dispute resolution, maintaining their friendly relationship and ensuring the voluntary implementation of what has been achieved.

The Jordanian legislator has a warned early the importance of mediation in the settlement of civil disputes and issued a special law regulating its provisions, Law No. 12 of 2006, which was amended by Law No. 25 of 2017.

This study focused on the most important results of the success of mediation in reaching a final settlement of the civil dispute in whole or in part, whether with regard to the subject matter of the same case or with respect to the right to recover fees paid .
\end{abstract}

key words:(Civil suit, mediation, settlement, friendly solution ) 


\section{مقدهة}

لـم يـرد في قـانون أصـول المحاكمـات المدنيـة الأردنـي. (') أي تعريـف للـدعوى المدنية، في حين يعرفها بعض الفقهاء بانها الوسيلة التي يتوسل بها صساحب الحق القئ

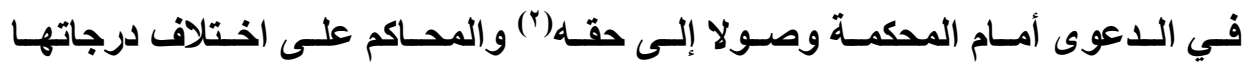
واختصاصاتها هي صاحبة الولاية في نظر المنازعات المدنية التي ترفع اليها مراعية

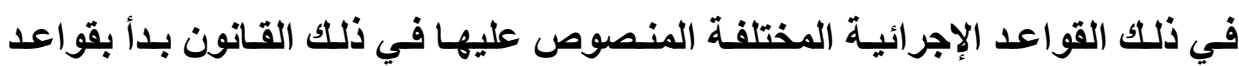
اختصاصها وانتهاء بأحكام فاصلة في تثلك المنازعات تبين مآل الحق المتنازع عليه(") ويمجرد رفـع الـدعوى مـن قبـل المـدعي، وقيـدها لـدى المحكمة تنـشأ عنهـا الخصومة القضائية التي تستمر إلى حين انتهائها بالفصل في موضوعها وعن أو بانقضائها

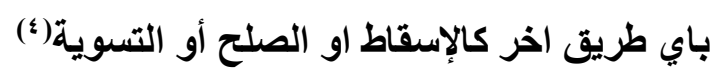
ومن البـيهي ان الدعوى المدنيـة تحتـاج كثيرا مـن الجهد يبذلـه المدعي في

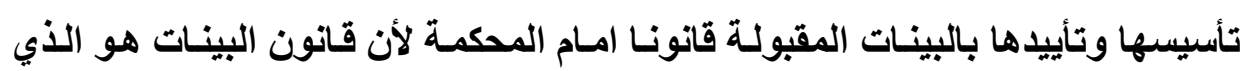
يحدد أنواع البيانات، ووسائل الاثبات، ومدى جوازها في اثبات الحقوق المدعى بهاب(ه)

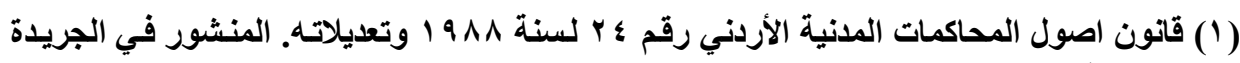

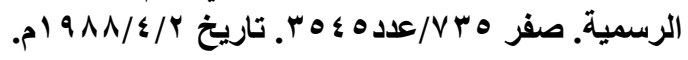

(2) https://www.law-arab.com/2016/11/lawsuit-definition-language 22/1/2019

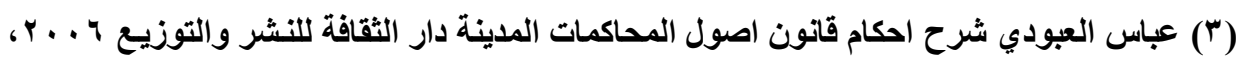

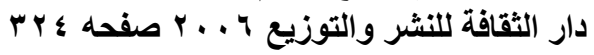

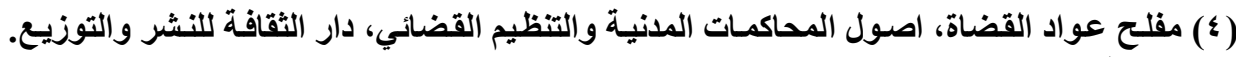

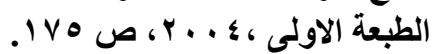

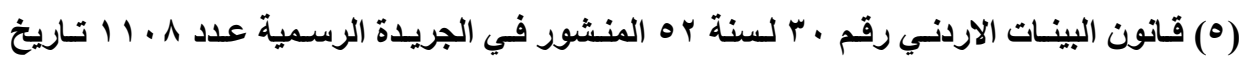

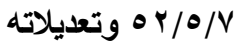


ذلك ان الأصل في الذمة هو البراعة وفق نص المادة "Vr" من القانون المدني الأردني

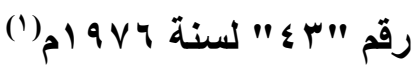

ويعزف الكثير من أصحاب الحقوق عن اللجوء إلى القضاء للمطالبة بها إمـا

بسبب الجها والمشقة في رفع الدعوى المدنية ومتابعتها او بسبب الرسوم والنفقات والمصاريف والأتعاب التي تحتاجها ، أو لطول أمد التقاضي في معظم الأحيان او حفاظا على العلاقـات وديـا مـع مدينيهم، او لعدم رغبتهم في كشف وعرض منازعـاتهم امسام

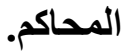

وعليه فإنـا نلحظ ان كثيرا من هؤلاع لايه ميل لحل خلافاته المالية مـع خصومه

بالطرق الودية لما فيها من حفاظ على طيب العلاقات وسرعة في الوصول إلى تسوية تكون مرضية لأطر افهـا وبالتـالي خضوع طوعي لتنفيذ بنودهـا ، وقد تتبـه المشرع الأردني مبكر الهذه المسائل ، مقدرا ان العدالة قد تقتضي الحلول الوديـة ذات المرونـة والسرعة والمنطوية على الرضا أكثر مما تؤدي إليه الاحكام القضائية التي تقوم على القسر والجبر سواء في إصدارها أوفي تنفيذها، لذلك تبنى بعض النظريـات الحديثة في تسوية المنازعات المدنية بالطرق البديلة حيث كرس ذلك في قانون أصول المحاكمـات

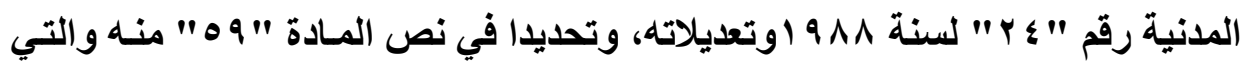
تتضمن انشاء إدارة للاعوى المدنية في محاكم البداية وحدد اختصاصات وصلاحيات

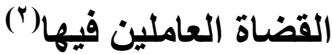

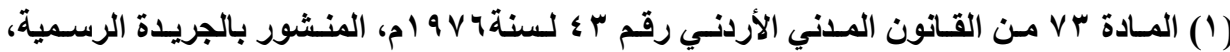

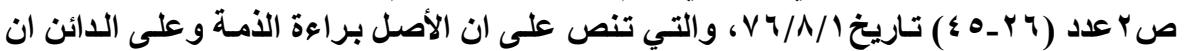

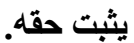

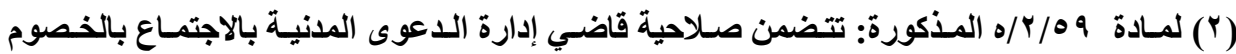
وحثهم على حل النزاع وديا بينهر 
وكذلك في قانون الوساطة لتسوية النزاعات المدنية رقم "ץ ا " لسنة ج ؟ . ب م وتعديلاته(') وتعد الوساطة احدى الوسائل البديلة لتسوية المنازعات المدنية، وهي تنم بالتدخل بين أطراف الخصومة وتقريب وجهات النظر بينهم في شـأن النزاع وذلك من اجل انهائه(؟)ويعرفها البعض بانها وسيلة يتم بمقتضاها تلخل شخص من الغير كوسيط

اثناء مفاوضات انهاء المنازعة (ت)

ومن الجدير بالذكر ان اللجوء إلى الوسـاطة وتدخل طرف ثالث لأجرائها بين أطراف النزاع يقوم على اختيار هؤلاء الأطراف ورضاهم وتوافر النية المشتركة لليهم لحل النزاع وانهائه بالوساطة(؛) وبالنظر إلى ان الوساطة تعد وسيلة استثنائية لتسوية النزاع سواء من حيث اللجوء اليها أومن حيث النتيجة التي تؤدي اليها وهي تسوية النزاع وإنهائسه، فإنتـا نعتقد ان توافق الأطراف على الوسيط يعد أمـرا لازمـا لإنجـاح مساعيه في الوساطة بينهم، فلا يمكن ارغام أي من الأطراف على تسوية النزاع من

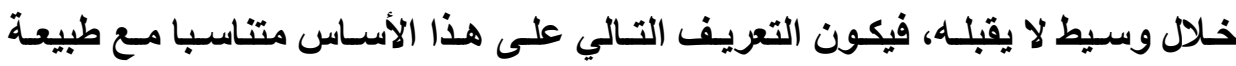
الوسـاطة الاختياريـة من جميع الوجوه فهي وسـيلة اختياريـة لأطراف النزاع المـدني سواء من حيث اللجوء اليها أو من حيث الوسبط القائم عليها أو من حيث التسوية الناتجة عنها، ويؤكد سلامة هذا التعريف وصحته بأن ثمرة نجاح الوساطة هي التسوية

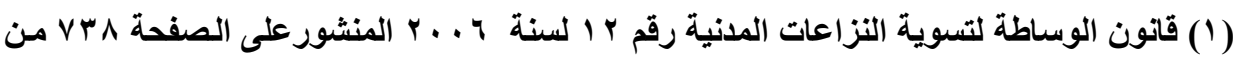

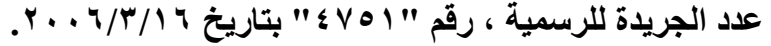
(ץ) محمد نصر الرواشدة، ادارة الدعوى المدنية في النظام النام القضائي، دراسة مقارنه دار الثقافة للنشر

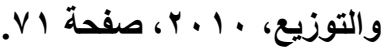

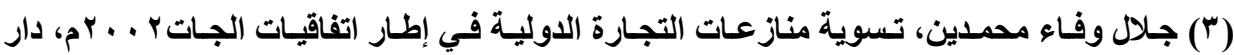

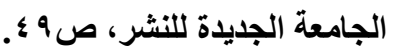

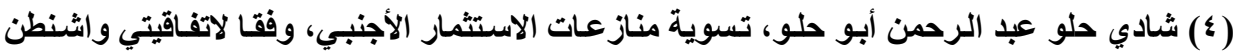

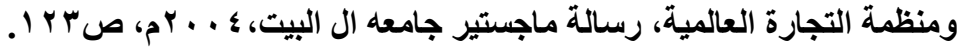


التي يتوصل اليها الأطراف لإنهاء النزاع ودون أدنى شك فان التسوية تعد عقدا مبرمـا بين أطراف النزاع انهاء له وتستلزم بالتالي جميع اركان العقد وشرائطه(') ولمسا كانت نتيجة الوسـاطة رهينـة برضـا الأطراف، فبان من المحتمـل ان يفشل الوسيط معهم في تسوية النزاع والوصول إلى حله مثلمـا يحتمـل ان يصل معهم إلى التسوية التي تعقد برضاهم في ظل إجراعات مساعيه وجهوده المبذولة لتقريب وجهات نظرهم واقتراح

بعض الحلول الإيجابية الناجعة المؤدية إليهاب(؟)

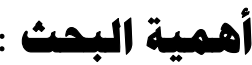

تبدو اهمية البحث في ضوء النظرة التشريعية الحديثة وبالتالي ضرورة اللجوء

إلى التسوية الودية لحل النزعات المدنية وان كانت قد قيدت دعاوى في شـأنها وذلك للسمات الإيجابية العديدة لهذه السبل فرضا الخصوم بالحل الودي يحافظ على علاقتهم مستمرة ويعزز بالتالي استمرار تعاونهم اضافة إلى سرعة الوصول اليهه ممـا يزيــ من رضا صاحب الحق فيما نجم عن اتفاق تثاركي مع خصمه، أضف إلى ذلك ان الوسـاطة في حال نجاحها تخفف عبئا كبيرا عن كاهل المحاكم المدنية. إشكالية البمث: يشكل قـانون الوسـاطة لتسوية النزاعـات المدنيـة الأردنـي رقم "ب ا " لسنة

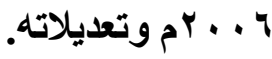

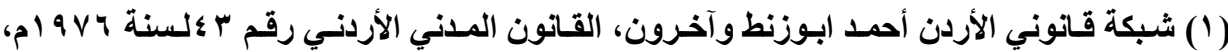

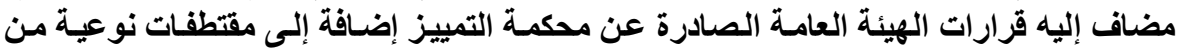
المذكرة الايضاحية للقانون المدني، دار وائل للنشر والتوزيع، ص صـ ؛ ؛ (r) الدكتور محمد إبراهيم موسى، التوفيق التجاري الدولي وتغير النظرة السائدة حول سبل تسوية

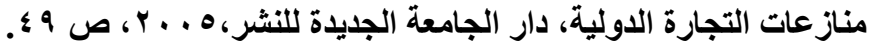


التظيم القانوني الأساس للوساطة بأنواعها المختلفة غير ان المشرع قـ أشسار

إلى دور قاضسي ادارة اللدعوى المدنيـة في الوسـاطة في المسادة وه مكرر من قـانون

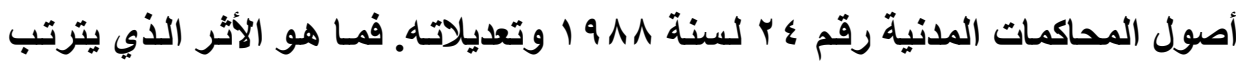
على نجاح الوساطة سواء بالنسبة لتسوية النزاع وإنهائهـ او بالنسبة للمسائل المالية المرتبطة بها وحقوق الوسيط وأتعابه؟.

\section{عناصر الاشكالة:}

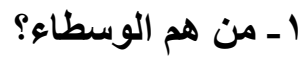

r ـ ما هو دور قاضي ادارة الدعوى المدنية في إجراءات الوساطة ؟ rـ ما هي طبيعة التسوية الناجمة عن الوساطة في حال نجاحها سواء قبل تصديقها

$$
\text { او بعده ؟ }
$$

ع ـ هل لقاضي الموضوع بعد وصول النزاع إليه إعادته إلى الوساطة ؟

ه ـ كيف نقدر اتعاب الوسطاء ومن الجهة التي تتحملها ؟

$$
\text { \ـ ما هي الدعوى المدنية التي تقبل الوساطة ؟ }
$$

ويتبع الباحث في اجراء هذا البحث المنهج الوصفي التحليلي لاراسة النصوص القانونية ذات العلاقة بالموضوع وذلك للإجابة على تلك الإثكالية والعناصر المتفرعة

وتحقيقا لذلك قسم البحث إلى المبحثين الرئيسين التاليين:

المبحث الأول: أثر نجاح الوساطة على موضوع الدعوى المدنية.

المبحث الثاني:أثر نجاح الوساطة في الدعوى المدنية على تبعاتها المالية. 


\section{المبمث الأول \\ أثر نجاج الوساطة على موضوع الدموى المدنية}

من البديهي ان جهود الوساطة إذا لم تسفر عن تسوية بين الفرقاء مهمـاكـان النـزاع المـنـي يبقى قائمسا بينهم وتظل الخصومة القضائية بالتـالي ماثلـة في نطـاق اللدعوى ممـا يقتضي معه إحالـة هذه الدعوى إلى قاضسي الموضوع للنظر فيها وفقا

للقواعد المقررة في قانون أصول المحاكمات المدنية(')

والـدعوى المدنيـة التـي تخضع للوسـاطة هـي الـــوى الـصلحية والـدعوى

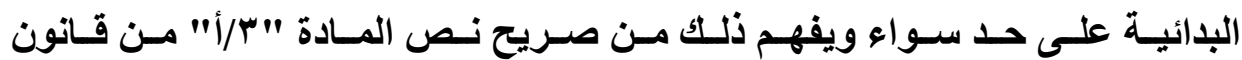
الوسـاطة، والتي تتضمن صـلاحية قاضسي إدارة الـلـعوى المدنيـة في إحالـة الـدعوى التـي تحست يــده إلـى الوسـاطة سـواء بنـاء على طلب أطـراف النـزاع أو ومـوافقتهم على عرضـه بالإحالة، ووفقـا لنص المـادة "وهـ" مكرر من قانون أصول المحاكمـات المدنية فإن الدعوى التي تكون تحت يد قاضي إدارة الدعوى بمجرد قيدها هي الدعوى البذائية العاديـة، دون اللدعوى التي تنظر بصفة الاستعجال فهذه الأخيرة يتعين على المحكمة تحديد موعد للمحاكمة فيها فور قيدها مع مراعاة المدد الخاصة لتبادل اللوائح

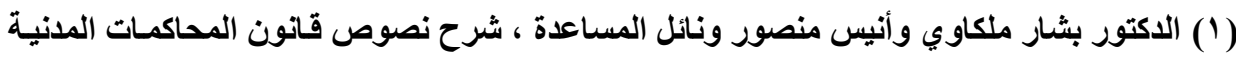

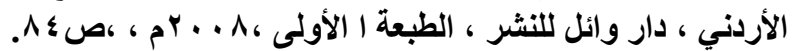

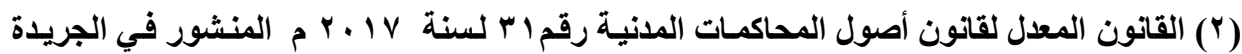

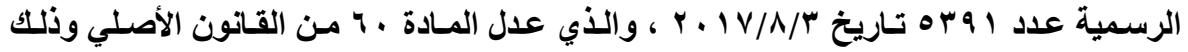

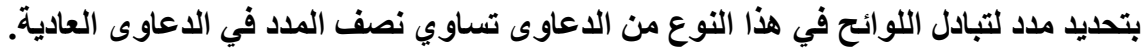


من جهة أخرى فإن لقاضي الصلح أيضا الذي ينظر اللدعوى الصلحية إحالة

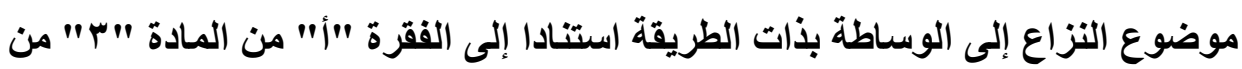
قانون الوساطة السابق ذكر ها.

\section{المطلب الأول \\ الصلاحية في الوساطة}

رغم أن المتمعن في نصوص قانون الوسـاطة لتسوية النزاعات المدنية يدرك

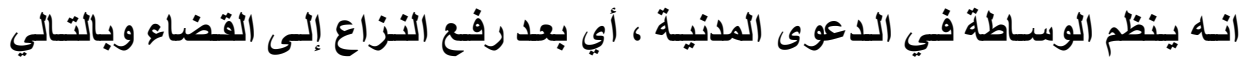

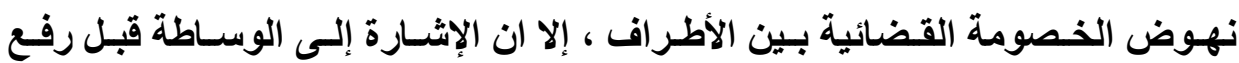

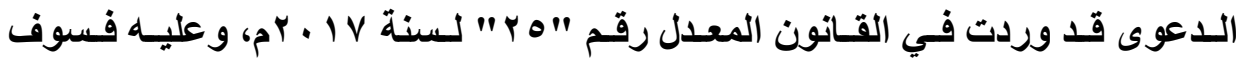
نتعرض لاراسة الصلاحية في الوساطة في حالاتها المختلفة

\section{الفرع الأول : الصلاحية في الوساطة قبل رفع الدعوى}

تبنى المشرع نوعـا جليدا من الوسـاطة وهو الوسـاطة السـابقة على الدعوى

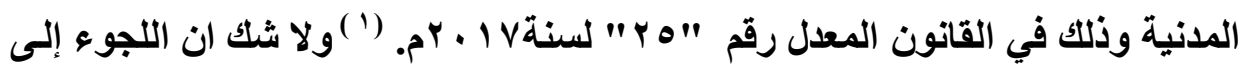
الوساطة قبل رفع الدعوى لتسوية النزاع القائم يعود للفرقاء أنفسهم واما ان يأتي ذلتك

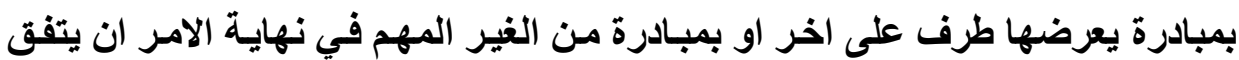

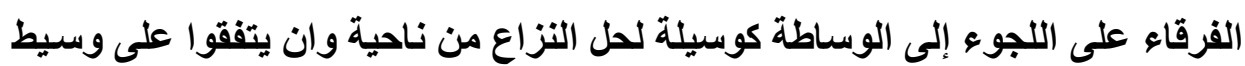
معين يتولى جهود الوساطة لحل النزاع.

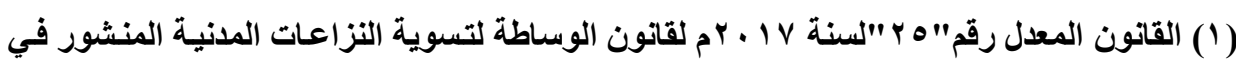

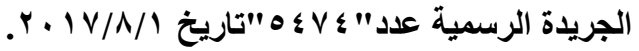


وعليه فـان صـلاحية اللجوء إلى الوسـاطة لحل نزاع مدني معين تعود لاتفـق

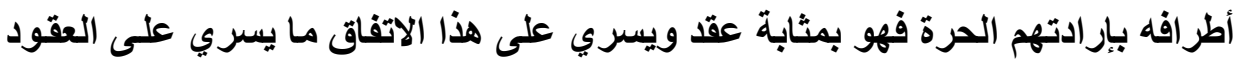
بشكل عام. وقد يأتي اتفاق الأطراف على اللجوء إلى الوساطة كواحدة من السبل الودية لحل النزاعـات المدنية بصورة شرط في عقد ينظم العلاقة الاصلية التي ثـار بشأنها

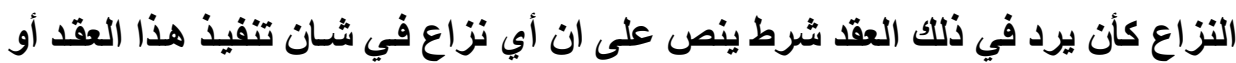
تفسيره يحل باللجوء إلى الوساطة. وإما ان يلتزم الأطراف بهذا الشرط في شان أي نزاع ينشا بينهم حول ذلك العقد او ان يلجأ أحدهم إلى القضاء للفصل في هذا النزاع متجاهلا شرط التران الوساطة.

\section{الفقرة الأولى : التزام أطراف النزاع بشرط الوساطة}

ذكرنا أن مباشرة الوسيط لأعمـال الوسـاطة في مثل هذه الحالـة يستلزم توافق

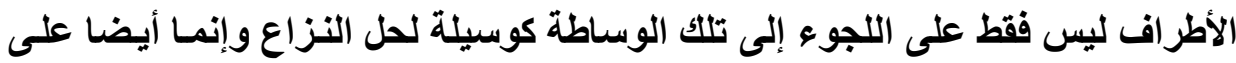
الاتفـاق على وسيط معين لإجراء تلكت الوسـاطة، ويحدد الاتفـاق مـع الوسيط كطرف

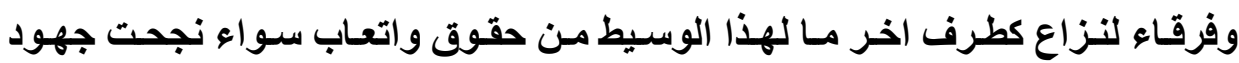
الوساطة واسفرت عن حل للنزاع برمته

\section{أو نجمت جزنيا او نشلت في الوصول إلى ذلك الهل :} أ- تسوية النزاع بالوساطة السابقة على الدعوى

إن تسوية النزاع بالوساطة تعني وصول جهود الوساطة إلى اتفاق بين الفرقاء

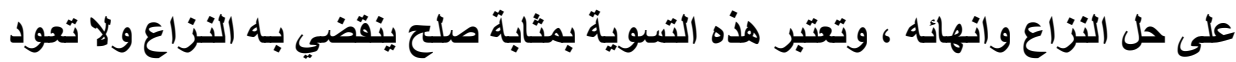

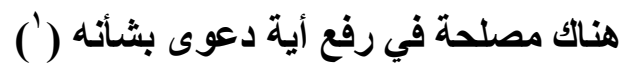




\section{ب- تسوية النزاع جزئيا بالوساطة السابقة على الدعوى.}

في حال نجحت جهود الوسيط في حل جزئي للنزاع وجرت التسوية في شأن هذا

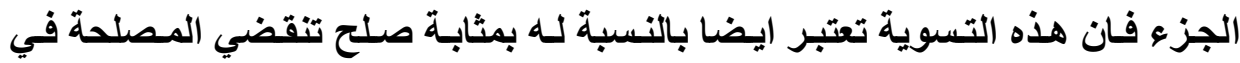
المطالبة به ولا يعتبر بالتالي من قبيل التتازلات التي لا يعتد بها القانون فالمـادة الثانية من القانون المعدل لقانون الوساطة لتسوية النزاعات المدنية والتي عدلت المادة الثانية من القانون الاصلي بحيث اصبحت هذه المـادة تسري على اية وسـاطة وإن تمت قبل

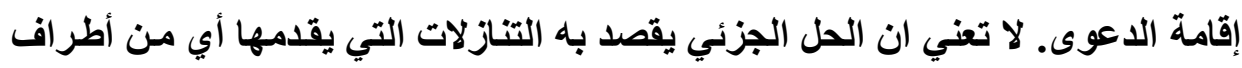

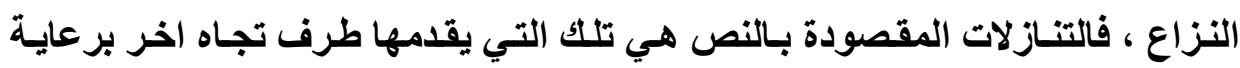
الوسيط ودون أن تسفر عن حل للنزاع فيظل الحق على حاله ولا تؤُثر هذه التنـازلات

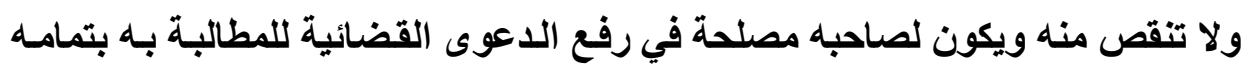
غير منقوص ولا متأثرا بتلك التنازلات التي كانت غايتها فقط دفع عجلة الوساطة نحو لإنها الوصول إلى حل للنزاع والاتفاق على تسوية بشأنه، وقابلية التمييز بين التسوية من

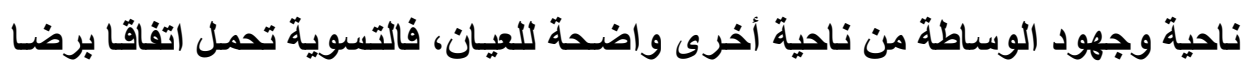

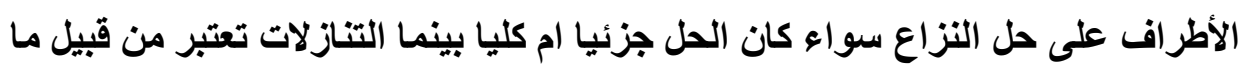

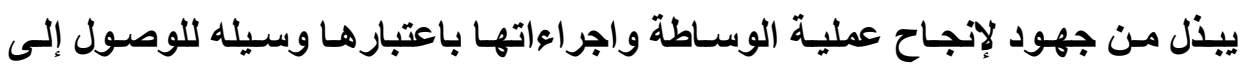

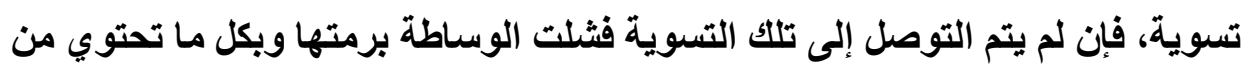

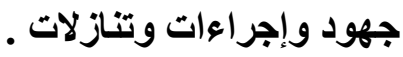

\section{الفقرة الثانية : عدم التزام الفرقاء بشرط الوساطة}

قد يتقدم أحد أطراف العلاقة القانونية إلى القضاء برفع دعوى في ضوء علاقة

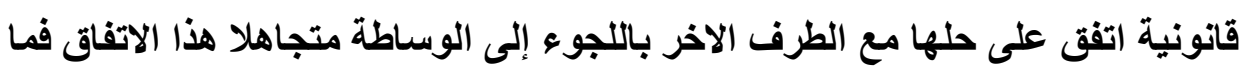
هو أثر ذلك على دعواه؟ تلفي على على 
وفقا للقو اعد العامـة فبإن الاتفـق على اللجوء إلى الوسـاطة يـذل في مفهوم اعتبار العقد شريعة للمتعاقدين بـالنظر إلى أنـه لا يخالف قاعدة آمرة ولا يمس النظام العام لكن هذا الاتفـق في ذات الوقت يتعلق بمصلحة الخصوم أنفسهم فـان لـم يتمسك لـك الخصم وهو المدعى عليه بإثارة هذا الدفع مـع لائحته الجوابية وضمن الوقت المحدد

لتقديمها سقط حقه في تقديمه فيما بعد (')

علما بان هذا الدفع يعد من الدفوع الثكلية لان التمسكك بـه وإن ردت الدعوى على أسـاسه لا يمنع من إقامة الدعوى مجددا بعد استنفاد فرصة اللجوء إلى الوسـاطة وعدم حسم النزاع وديا. وعلى الرغم من ان هذا الدفع لم يرد ذكره في القانون الا انتـا نرى ان الأخذ به أولى للأسباب التالية: أـ أنه شرط اتفاقي. وأنه أحد الالتزامـات المترتبة على عاتق الأطراف استنادا لمبدأ العقد شريعة المتعاقدين. بـ أن الدفوع الشكلية ليست جميعها واردة في القـانون فهنـاك دفوع شـكلية تـتم اثثارتها ويترتب أثرهـا على اللدعوى رغم عدم النص عليها صراحة مـن بين الدفوع الثكلية ومن امثلتها الدفع بعدم صحة الخصومة، والدفع بجهالة الوكالة والدفع بعدم الأهلية وغيرها، مما يمكن معـه القول ان الدفوع الثكلية وان كانت

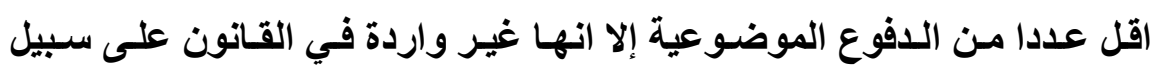
(الحصر (")

(1) المادة هـ 11 من قانون أصول المحاكمـات المدنية التي تتضمن أن الدفوع غير المتعلقة بالنظام العام يجب إبداؤها معا و إلا سقط الدق فيها.

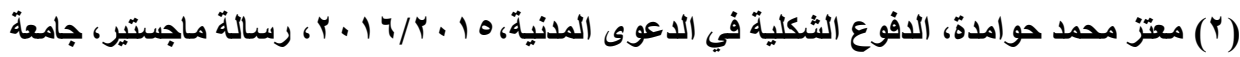

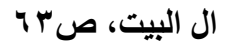


ج- إن الدعوى في هذه الحالـة تعتبر سـابقة لأوانهـا فهي مـن هذه الناحيـة تشبه

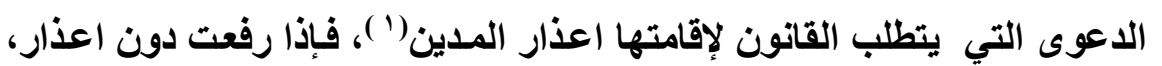
وتمسك المدعى عليه بعدم اعذاره ردت الدعوى لسبق أوانها. دـ يغني اللجوء إلى الوساطة عن رفع الدعوى في حال اسفرت عن حل ينهي النزاع

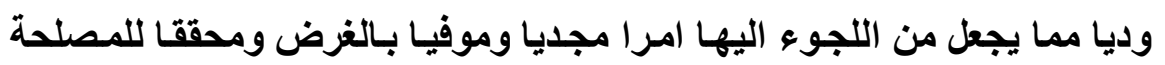
ومحافظا على العلاقة بين الأطراف طبيعية بسبب التشاركية في الوصول إلى حل ذلك النزاع.

وعليـه نرى بـأن قرار المحكمة برد الدعوى في هذه الحالـة يكون صحيحا إمـا بالاستناد إلى اعتبار الدعوى سابقة لأوانها بعدم استتفاد فرصة اللجوء إلى الحل الودي المتفق عليه، وإما بالاستناد إلى اعتبار الدفع بالحل الودي يعد دفعا شكليا ذا قيمة وللمدعى عليه مصلحة في إثارته والتمسك به، وبالتالي الإقادة من القرار

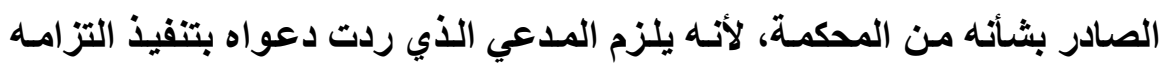
باللجوء إلى الوساطة كفرصة لحسم النزاع. هـ هناك تشريعات نصت صراحة على إلزام المحكمة بعدم قبول الدعوى المرفوعة إليها في حالة وجود اتفاق على الوساطة ومن أمثلتها قانون الإجراعات المدنية

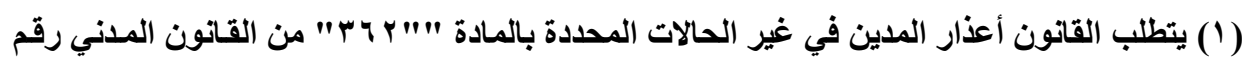

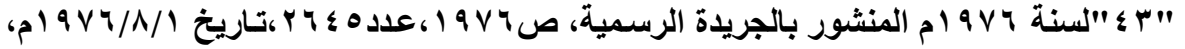

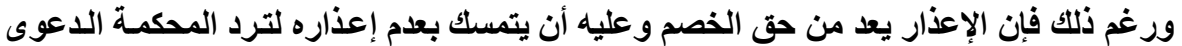

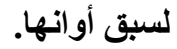


والإداريـة التونسـي لسنة ^ . . ب م والقـانون المعدل لقـانون المسطرة المدنيـة

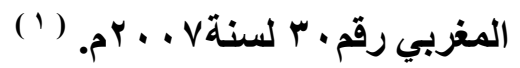

ومن الجدير بالذكر انه في حال لم تسفر الوسـاطة عن حل للنزاع فـان لصاحب المصلحة أن يرفع دعواه للمطالبة بحقه امام القضاء.

\section{الفرع الثاني : الصلاحية في الوساطة بعد رفع الدعوى المدنية}

سبق أن ذكرنا أن الدعوى العادية الخاضعة لتبـادل اللوائح تقع تحت يـ قاضسي ادارة الدعوى المدنية على خلاف الدعوى البلائية المستعجلة التي يسيطر عليها قاضي الموضوع بمجرد قيدها لنظرها بصورة مستعجلة بعد تبادل اللوائح الخاصة بها بصورة مستعجلة ، وبالرجوع إلى نص المادة وه/ امكرر من قانون أصول المحاكمـات المدنية نجد ان المشرع أيضا قد أعطى قاضي ادارة الدعوى المدنية صـلاحية عرض التسوية على الخصوم في الاجتمـاع الذي يعقده معهم بصورة وديـة ويبذل مساعيه لإقـاعهم بإجرائها ، وإلا عرض عليهم إحالة النزاع لعله بوساطة الوسطاء وفقا لقانون الوساطة

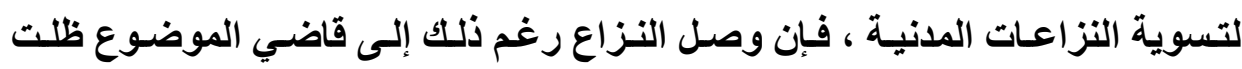
الفرصة قائمة امام الخصوم لطلب وقف الدعوى لغايات إحالة النزاع إلى الوساطة. الفقرة الأولى : الوساطة المباشرة لقاضي إدارة الدعوى المدنية يعرض قاضي إدارة الاعوى المدنية وساطته بين الخصوم في الاجتماع الودي الذي يعقده معهم وييذل مـا في وسسعه من جهود لتقريب وجهات نظرهم في سبيل التوصل إلى حل يرضي الطرفين وينجم عنه بالتـالي تسوية وديه منهية للنزاع بينهم 
فِان نجح في ذلك نظم هذه التسوية وطلب من الطرفين التوقيع عليها ثم يضمها إلى مخر خاص بإدارة الاعوى المدنية. ( )

\section{الفقرة الثانية : إحالة النزاع إلى الوسطاء}

وفقا للمسادة "ب" من قـانون الوسـاطة لتسوية النزاعـات العدنية فبان لقاضسي إدارة الدعوى المدنية أن يعرض على الأطراف إحالة النزاع إلى الوسـاطة بأنواعها

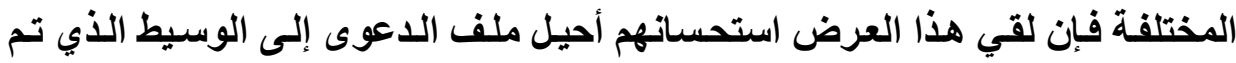
التو افق عليه، و الوسطاء حسب ذلك القانون ثلاثة أنواع وذلك على النحو الاتي: أـ الوسيط القضائي: وهو أحد القضاة المعينين في إدارة الوسساطة في محسكم البداية وتوكل إليه مهمة التوسط بين الخصوم في النزاع المدني الذي احيل إليه وبذل مساعيه وجهوده لتقريب وجهات نظرهم و إيصالهم إلى حل ودي يسفر عن انهاء النزاع بينهم ومن الجدير بالذكر ان القانون نص على ان يكون من بين هؤلاء قاضي صلح يتولى مهمة الوسـاطة بالنسبة للاعاوى الصلحية التي

$$
\text { تحال إلى الوساطة من قبل قاضي الصلح. }
$$

بـ الوسيط الخاص : والوسطاء الخصوصيون هم طائفة من المحامين والقضاة المتقاعدين وغيرهم من أصحاب المهن الذين يتسمون بالحيدة والنزاهة الذين يتم التنسيب بهم من قبل وزير العدل ويوافق عليهم رئيس المجلس القضائي

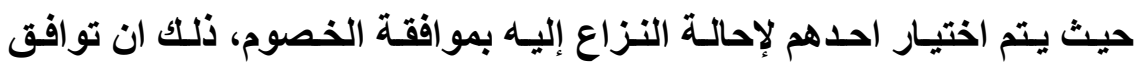
الخصوم على حل النزاع وديا وعن طريق الوساطة يتطلب بالضرورة مو افقتهم على شخص الوسيط او الوسطاء الذين يتم اختيارهم لهذه المهمة، ولا يتصور 
ان يجبر الخصوم او أحدهم على وسيط لا يرضـه لحل النزاع عن طريقه لأنسه ببساطة يستطيع ان يرفض عندئذ مشروع الوساطة برمته. كذلك فإن من اهم متطلبات رضا الخصوم بالوساطة ، توافقهم على وسبط معين او وسطاء معينين لحل نزاعهم من خلالهم وإلا فثل عرض الوساطة. وعليه فإنتا نرى ان يعدل المشرع نص المسادة ب/أ من قـانون الوسـاطة، بإلغاء عبارة (مراعـاة موافقة الخصوم مـا أمكن). إذ إن رضـا الخصوم تـتم مراعاتهـه كأولوية لقبول عرض الوسـاطة ولا يجوز فرض وسيط معين على الخصوم او أحدهم ليس فقط لأنـه سيعزف عن قبول الوسـاطة و إنمـا قد يرفض إجراءات الوسناطة فيما بعد ويكون بذلك سببا في افشالها وبالتالي ضياع الوقت والجها وإطالة امد التقاضي وهذا عكس ما يراد للاعوى المدنية.

جـ الوسـيط الاتفــاقي: أجـاز قـانون الوســاطة لتـسوية النزاعـات المدنيـة أن يتوافق الخصوم على وسيط تتم تسميته من قبلهم ليحال النزاع إليه ، لإجراء

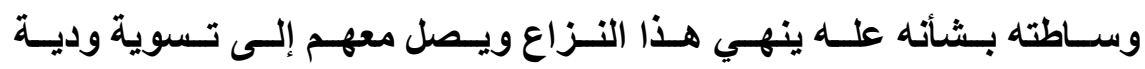
حيالـه، ونعتقــــان الفـرق الوحيــ بـين هـذا النـوع مـن الوسـطاء والوسـطاء الخصوصيون ان الفئة الاخيرة يتم حصر ها بقائمـة ينسب بها من وزير العدل ويوافق عليها رئسيس المجلس القضائي للتسهيل على الخصوم الاختيار منهم لإحالـة النزاع اليـه، بينمـا الوسطاء الاتفـاقيون يـتم اختيـار أي مـنهم والتوافق عليهم مباشرة من قبل الخصوم في النزاع المدني. مما يؤكد ما توصلنا اليهه من ضرورة اخذ رضا الأطر اف على الوسيط سواء كان خصوصيا او اتفاقيا او حتى قضائيا. 


\section{النقرة الثالثة : إحالة قاضي الموضوع النزاع إلى الوساطة}

إن المـتمعن بقـانون الوسـاطة لتـسوية النزاعـات المدنيـة رقـم "ب ا" لـسنة

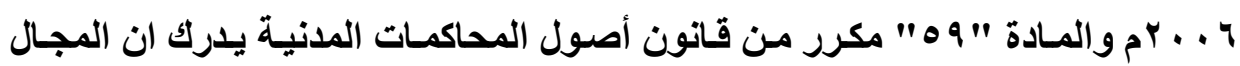
المرحلي والزمني للوساطة في الدعوى المدنية يكون قبل إحالـة هذه الدعوى لقاضي الموضوع ذلك ان الغاية منها حسم النزاع وانهائـهـ قبل هذه المرحلة وبالتـالي تفويت

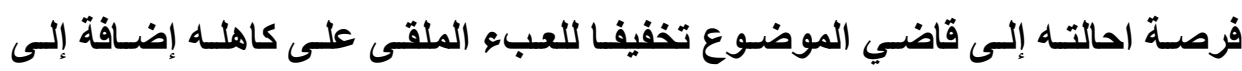
الإيجابيات الكثيرة الأخرى للتسوية الناجمة عن الوساطة.

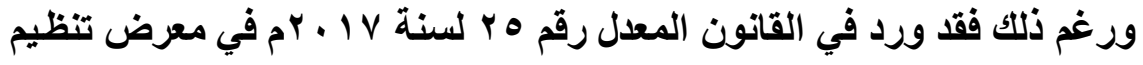
حقوق الخصوم باسترداد الرسوم القضائية وفي المـادة "ب" منـه والتي عدلت المـادة "q" من القانون الأصلي بإلغاء الفقرة أ منها والاستعاضة عنه بنص جديد يتضمن في الفقرة أ / منه، إن للخصم استرداد نصف الرسوم القضائية للاعوى البدائية في حسال تمت تسوية النزاع بالوساطة بعد وصوله إلى قاضي الموضوع.

وفي نظرنا فإن هذا النص وحده لا يعطي قاضي الموضوع صلاحية احالة النزاع إلى الوساطة، لأنه لا ينص صراحة على هذه الصلاحية على عكس النصوص القانونية الأخرى التي تعدد ابتـداء الصلاحيات وإجراءات تثفيذها، ثـم تـنظم مسألة استرداد الرسوم كأثر مسالي في حال نجـاح الوسـاطة بالوصول إلى تسوية. ومن المعروف ان الاعوى المدنية تسير في مجـال محدد ومسـار تحكمـه قواعد قانون أصول المحاكمـات المدنية ولا مجال إلى الاجتهاد فيها او القياس عليها فقاضي الموضوع لا يملك بعد بـء نظر الدعوى سوى وقف السير فيها بنـاء على طلب الخصوم(') وتسهيلا للحالـة التي

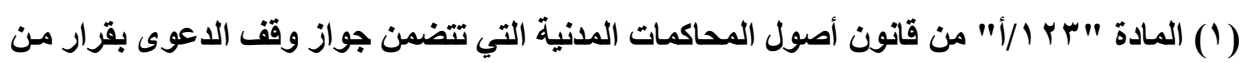
المحكمة بناء على اتفاق الخصوم مدة لاتزيد على ستة أثهر. 
نحن بصددها ولجعلها قابلة للتحقق يقرر القاضي بناء على طلب الخصوم وقف السير في الدعوى مده أقصاها ستة أثهر لغايات إحالة النزاع إلى الوساطة الاتفاقية لتسويته ودياً. وكان حريا بالمشرع في حال أراد منح قاضي الموضوع صلاحية إحالة النزاع إلى إنى الوسـاطة أن يوجد نصا يمنحسه بـه هذه الصلاحية، ثم يـأتي استرداد الرسوم في حسال نجاح جهود الوسـاطة.

وقد قصر التعديل هذه المسألة. فقط على الدعوى البدائية ولكن هذا لا يمنع أن يتخذ قاضي الصلح قرارا مبنيا على اتفاق الخصوم يوقف السير في الدعوى مده حدها الأقصى سـتة أشـهر ويستطيع عندئـــ الخصوم إحالـة النزاع إلى الوسـاطة الاتفاقيـة بمعرفتهم والوصول إلى تسوية هذا النزاع وإنهائه.

\section{المالب الثاني}

\section{المصادقة على التسوية الناجمة عن الوساطة}

تعتبر اتفاقية التسوية الناجمـة عن الوسـاطة شبيهة بالـصلح إلى حد كبير، فالصلح عقد بين طرفين ينقضي بـه نزاعهمـا(') غير انها تختلف عنه في كونها ثمرة لجهود وسـاطة ناجحة حققتها وأدت اليها ورغم ذلك فهمـا يلتقيـان في أنهمـا يقبلان الطعن بهمـا بـأي من عيوب الرضـاوعوارض الأهلية من قبل صـاحب المصلحة امـام

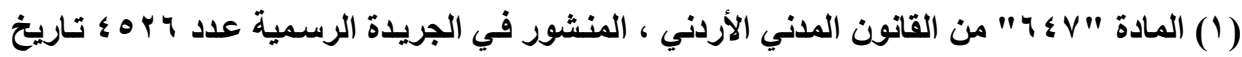

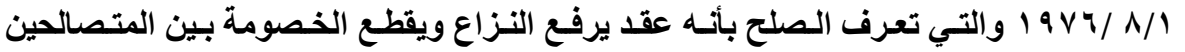
بالتراضي. 
المحكمة() لكن الامر يختلف في حال تمت المصادقة على اتفاقيّة التسوية، من قبل

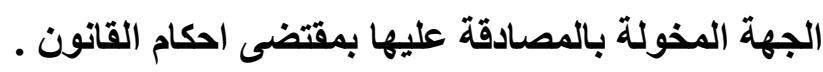

\section{الفرع الأول: سلطة القاضي في المادقة على التسوية}

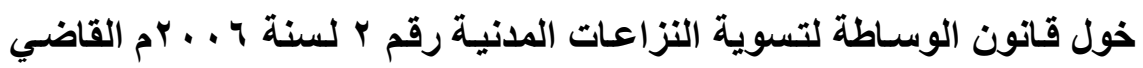
الذي أحال موضوع الدعوى للوسـاطة، سلطة التصديق على اتفاقية التسوية الناتجة عنها.

\section{الفقرة الأولى : سلطة قاضي الموضوع في التصديق}

قاضي الموضوع هو القاضي الذي يملك صلاحية نظر الدعوى واتخاذ القرار

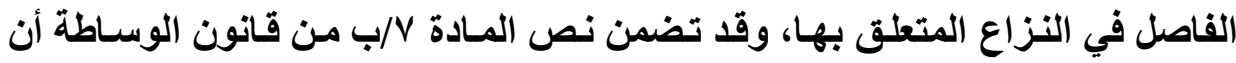

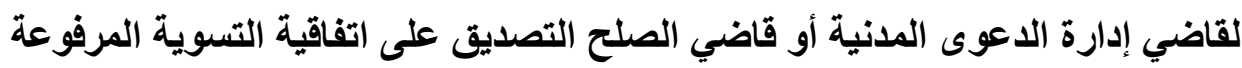
إليهه مـن الوسيط. وعلة ذلك أن قاضسي إدارة اللدعوى مسؤول عن الداعوى البدائيسة

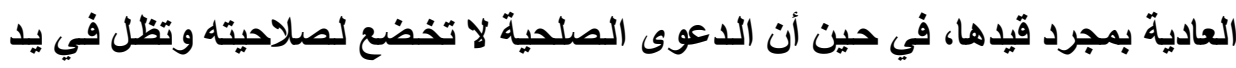

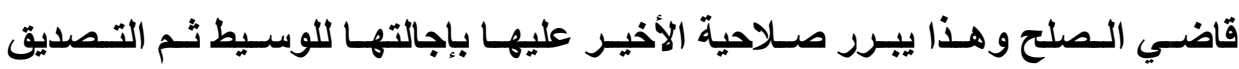

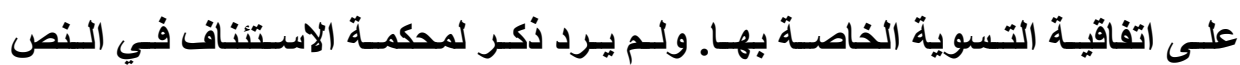
المشار اليه مما يجعلها بالتالي غير ذات صلاحيه في إحالة ملف الدعوى الذي يصل

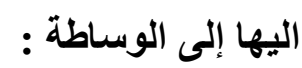

(1) عبدالقادر الفـار، مصادر الالتزام، مصادر الحق الثخصي في القانون المدني ـ الطبعة الأولى

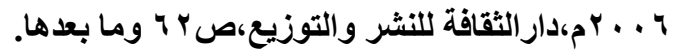




\section{أ- سلطه قاضي الصلح في التصديق على اتفاقيه التسوية.}

بالنظر إلى أن قاضي الصلح،هو الأي يحيل الدعوى الصلحية إلى الوسبط فبان على الأخير وبعد انهائه لإجراءات الوسـاطة ان يرفع تقريرا بأعمالـه مرفقا بـه اتفاقية التسوية الموقعة من قبل أطراف الدعوى الصلحية وذلك لتصديقها (')

ومن الجدير بالأكر ان قاضي الموضوع الصلحي الذي يملك صلاحية التصديق على اتفاقية التسوية يختلف بطبيعة الحال عن قاضي الصلح الوسيط الذي ورد ذكره في

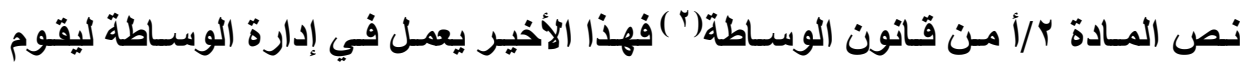
بإجراءات الوسـاطة في شـأن ايـة دعوى صلحيه تحسال اليهه من قبل قاضسي الموضوع الصلحي.

\section{ب - سلطة قاضي البداية في التصديق على اتفاقية التسوية}

لم يرد أي ذكر لقاضي البداية في قانون الوساطة لتسوية النزاعات المدنية رقم

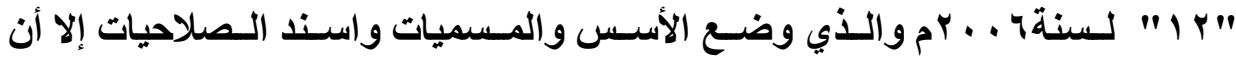
القانون المعدل رقم"ه ب" لسنة VI ـ ب م. أورد نصا وحيدا ذكر فيه قاضي البدايـة في معرض الدايث عن رد الرسوم وهو نص المادة ب/أ من القانون المعدل. (والذي سبقت الإشارة إليه) والذي يتضمن رد نصف الرسوم القضائية إذا تمت التسوية بعد إحالة الدعوى إلى قاضي الموضوع ومن المعلوم أن الدعوى تحال إلى قاضي البداية باعتباره قاضي الموضوع من قبل قاضي إدارة الدعوى المدنيـة في حـال عدم حل النزاع وديـا،

(1) قاضي الصلح هو القاضي الذي ينظر الدعوى الصلحية والمحددة صلاحيته على سبيل الحصر في

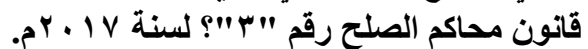

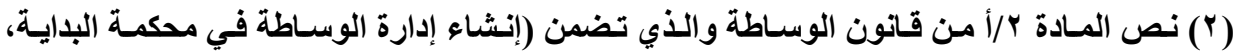
وتعيين عدد من قضاة البداية والصلح فيها يسمون قضاة الوساطة. 
وذلك لنظرها واتخاذ القرار الفاصل في النزاع بين خصومها في ضوء قواعد قانون أصول المحاكمـات المدنية. لكن القـانون لم ينظم احكام تمسام التسوية القضائية امسام

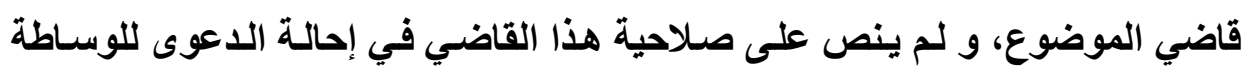

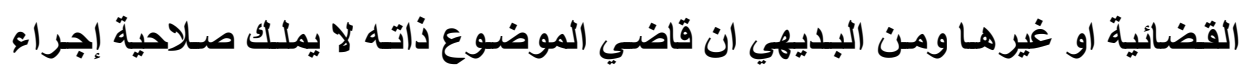

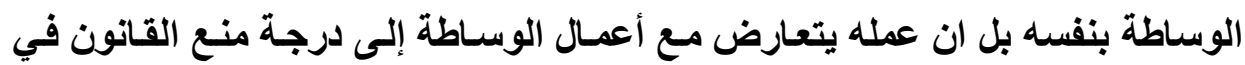

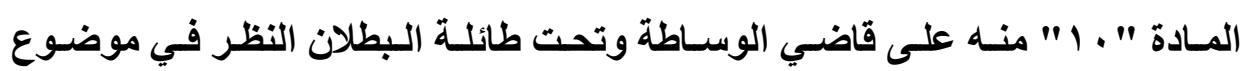
الاعوى التي سبق وان احيلت إليه للوساطة.

ولعل قاضي البداية كما سبق أن ذكرنـا يملك فقط أن يأمر بوقف الدعوى بنـاء

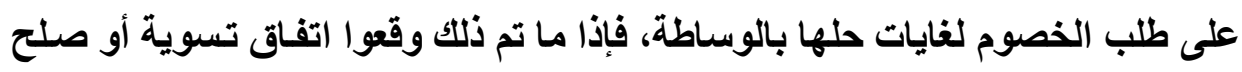

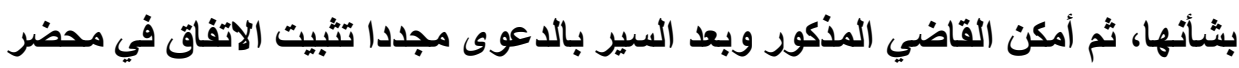

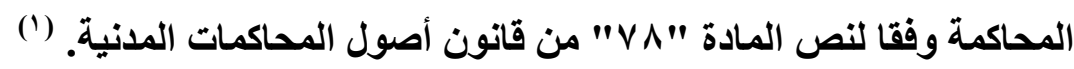

الفقرة الثانية : سلطة قاضي ادارة الـدعوى المدنيسة في التصديق على اتفـاق التسوية

سبقت الإثارة إلى نص المادة V/ب من قانون الوساطة والذي يتضمن صلاحية قاضي ادارة الاعوى الددنية بالتصديق على اتفاقيه التسوية التي ترفع اليه من قبل التبل

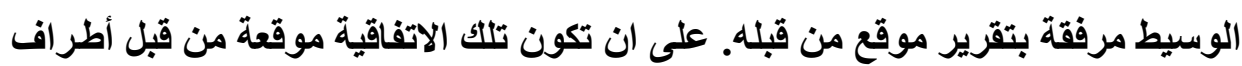
النزاع.

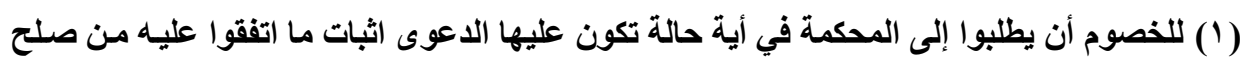

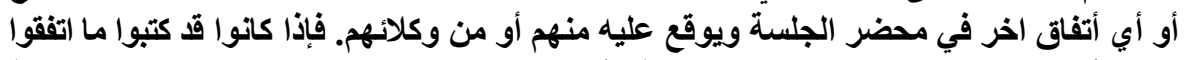

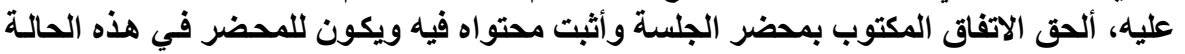
قوة الحكم الصادر عن المحكمة وتعطي صورته وفقا للقو اعد المقررة وفقا للإحكام. 


\section{الفرع الثاني : طبيعة القرار بالمادقة على اتفاقيه التسوية}

تكفل القـانون بإعطاء القرار الصـادر بالمصادقة على اتفاقيـه التسوية سـواء

جرت المصادقة من قبل قاضي إدارة الدعوى المدنية او قاضسي الموضوع صفة القرار القضائي الفاصل في النزاع غير ان هناك اختلافـا جوهريـا في طبيعة القرار من حيث قابليته للطعن اعتمادا على النص القانوني الذي يحكمه.

الفقرة الأولى : طبيعة القرار بالاصادقة على اتفاقية التسوية بمقتضى قتانون اصـول

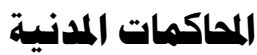

لقد أعطت المسادة "وهـ" مكرر من قـانون أصسول المحاكمـات المدنيـة لقاضسي ادارة الدعوى المدنيـة صـلاحية قاضسي الموضسوع في التصديق على اتفاقيـة التسوية وتثبيث الصلح حسبما تقضي به المادة "VA" من هذا القانون، وبـالرجوع إلى النص المذكور نجده يعطي المحكمة اثبات مـا أتفق عليه الخصوم من صلح او أي اتفـق اخر وهذه العبارة تثثمل اتفاقية التسوية الناجمة عن وسـاطة قاضسي ادارة الدعوى المدنيـة والجهود المبذولة تجاه طرفي النزاع، فاذا وقعت هذه الاتفاقية من قبلهم وألحقت في

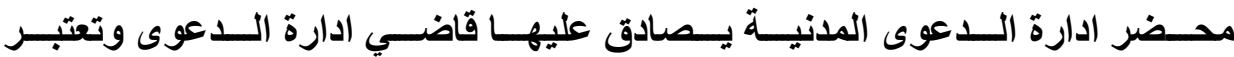
عندئــ وبموجب المـادة "VA" مـن قـانون أصسول المحاكمـات بمثابـة حكم صـادر عن محكمسة، وتعطي صـورته للخصوم على اعتبـار انـه حكـم قضائي. وبـالنظر إلـى أن اتفاقية التسوية تعتبر بمثابة حكم قضائي فإنها تخضع لمسا تخضع لـه الاحكام القضائية الصادرة عن محكمة الارجة الأولى من حيث قابليتها الطعن ويعتبر التصديق من قبل قاضـي الموضوع على اتفاقية التسوية من بـاب أولى بمثابـة حكم قضائي فاصل في النـزاع لأن نـص المـادة "VA" وجـا أصـلا لإضـفاء هـذا التكيـف علـى قـرار قاضـي الموضوع. 
الفتـرة الثانيسة : طبيعـة القـرار المصادقة على اتفاقيسه التسوية بمقتـى قـانون الوساطة لتسوية النزاعات المدنية

بموجب نص المادة "V/ب" من قانون الوساطة لتسوية النزاعات المدنية فإن

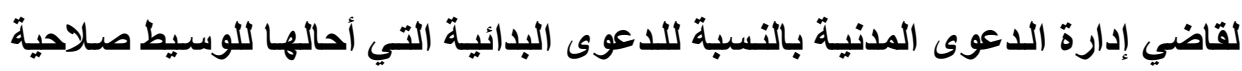
التصديق على اتفاقية التسوية الموقعة من أطراف النزاع وتعتبر بعد التصديق عليها لإيها بمثابة حكم قطعي.

وهذا يعني أن القانون قـ اغلق الباب على الطعن بالاتفاقية المذكورة بمجرد

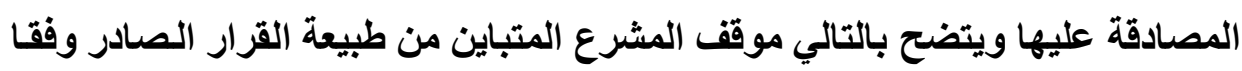

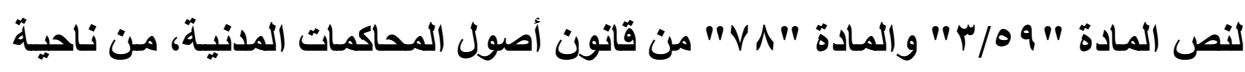

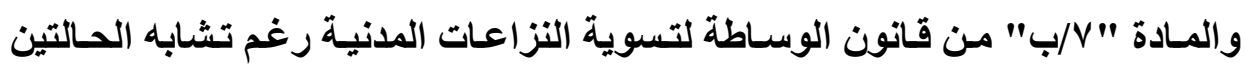

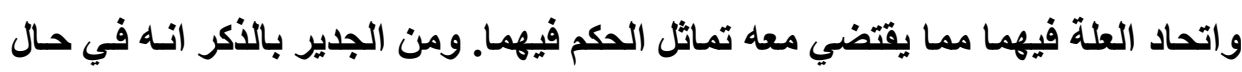

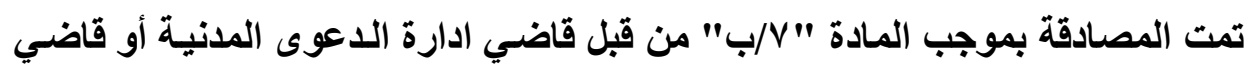

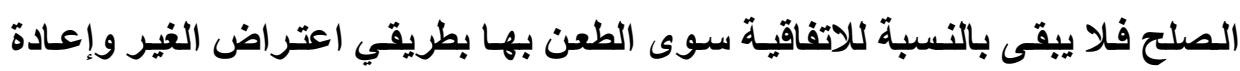

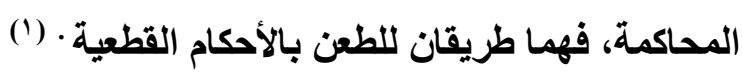




\section{المبمث الثاني \\ أثر نجاج الواسطة في الدعوى المدنية على تبعاتها المالية}

لا نقصد بالتبعات المالية هنا موضوع الدعوى المـالي او الذي يقدر بالمـال وإن

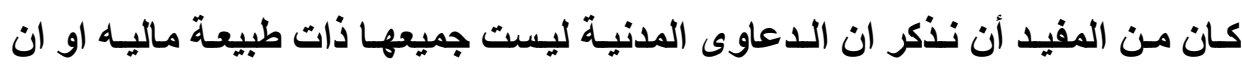
المطلوب فيها دائما يكون ماليا فمثلا دعوى اثبـات الجنسية التي يرفعها المدعي امسام

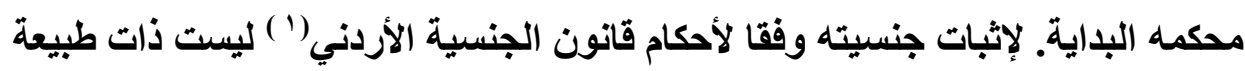
مالية ولا تقبل بالتالي من وجهه نظرنا الوساطة فيها، ودعوى تغيير الاسم ايضا التي يرفعها المدعي لتغيير اسمه(؟) لا تقبل الوساطة، علما بان المسألة لا علاقة لها بوجود الدولة طرفا في الدعوى بوصفها سلطة عامـة وانمـا بطبيعة الدعوى ذاتها فالدعوى بان المدنية التي تكون الدولة فيها طرفا بوصفها شخصا عاديا تقبل الواسطة، لأنها تملك حق اجراءات التسوية على حقوقها فيها، ونرى تبعا لذلك ان مـا يقبل الوسـاطة من الاعاوى هو ذاته ما يقبل الصلح لان التسوية الناجمة عن الوسـاطة، تعد بمثابـة صلح بين أطرافها. وقد بحثنا في المبحث الأول أثر نجاح الوسـاطة على موضوع الهو الدعوى

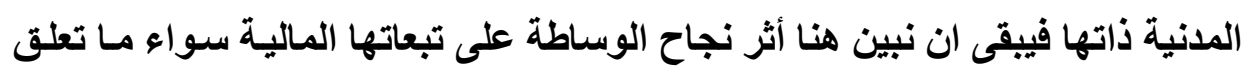
منها بالرسوم القضائية أو بأتعاب الوسطاء.

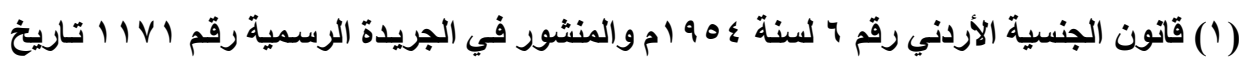

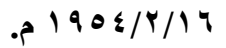

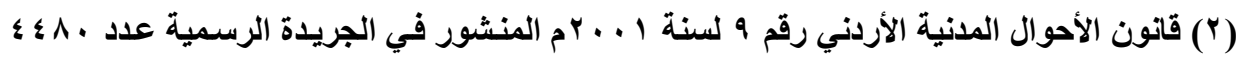

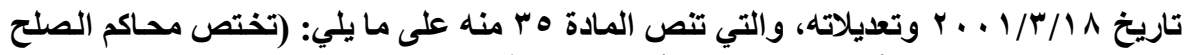

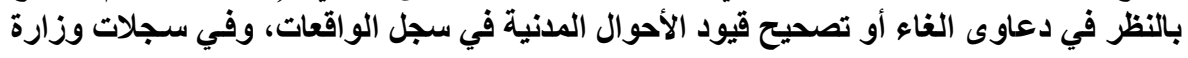

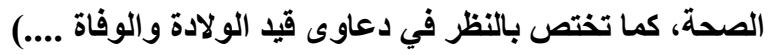




\section{المباب الأول}

\section{رد الرسوم القضائية}

يرى جانب من الفقه ان القضاء مجساني وان الرسـوم القضائية لا تؤثرث في مجانية القضاء(') ولعل مرد هذا الرأي أن سلطة الفصل في المنازعات بين الافراد تعد الفاء

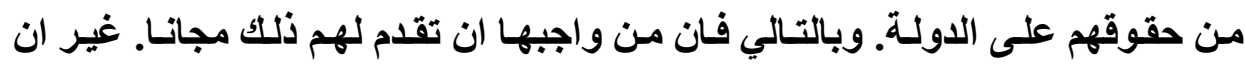
المجانية من وجهة نظرنا تعني عدم تقاضي اية رسوم قلت او كثرت وان استيفاء مثل

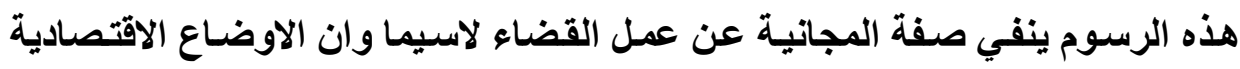

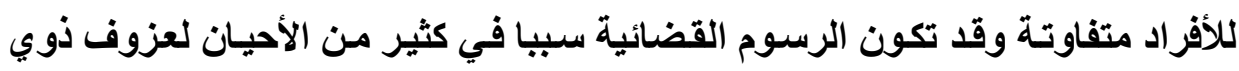
الاخل المتدني عن رفع دعوى قضائية للمطالبة بحقوقهم.

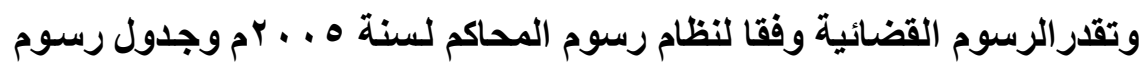
المحاكم الملحق بـ(") دون اغفال النفقات الاخرى من رسوم طوابع وتصديق وثنائق

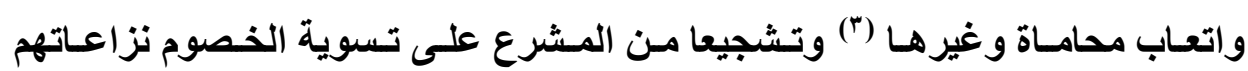

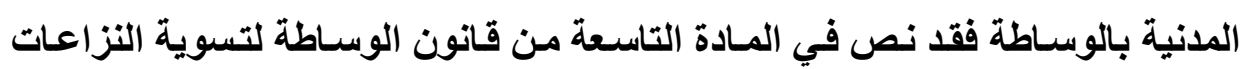
على أحكام استرداد الرسوم القضائية ومقار ما يسترد منها.

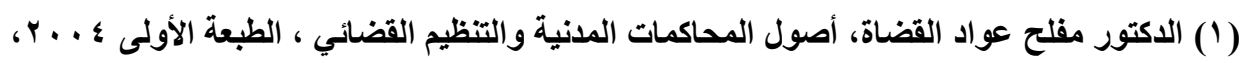

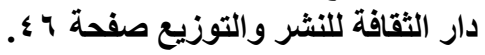

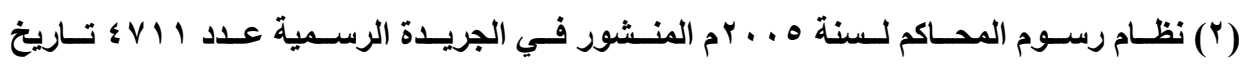

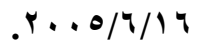

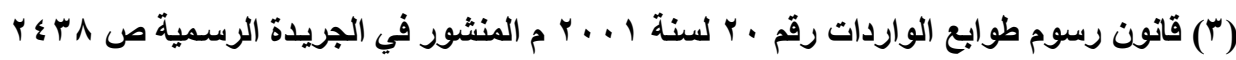

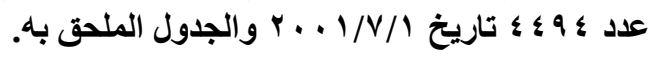




\section{الفرع الأول : رد الرسوم نتيجة الوساطة القضانية}

الخل المشرع على المادة التاسعة من قانون الوساطة لتسوية النزاعات المدنية

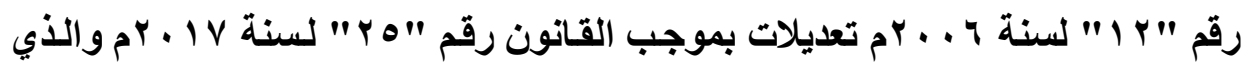
سبقت الإثـارة اليه. ويفهم مـن عبـارة أن (للخصوم استرداد) أن للمدعي مـن ناحيـة وللمـدعي عليهه في حسال كانـت لـه دعوى متقابلـة مسن ناحيـة أخرى استرداد الرسـوم القضائية المدفوعة من قبله سواء كانت الاعوى المدنية بدائية أم صلحية مـع اختلاف في مقدار الاسترداد من تلك الرسوم وذلك على النحو التالي:

\section{الفقرة الأولى : رد الرسوم القضانية في الدعوى البدانية}

اللاعوى البدائيسة هـي الدعوى التي تنظرهـا محكمه البدايـة باعتبارهـا صـاحبة

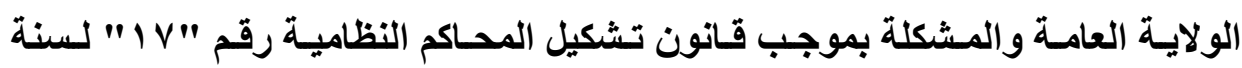

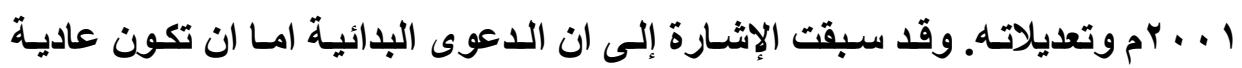

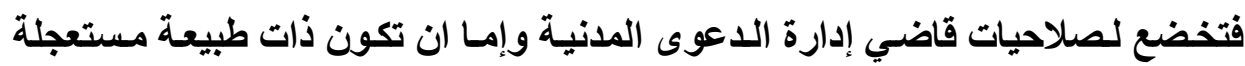
فتحال إلى قاضي الموضوع لنظرها وهي المنصوص عليها بالمـادة " ـ ؟" من قانون اصول المحاكمات المدنية. وقد ميز المشرع في مقدار الرسوم القضائية المستردة من

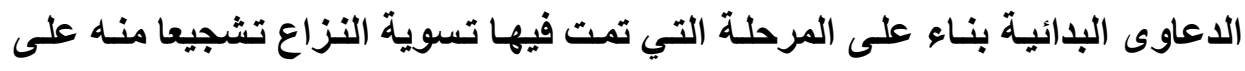

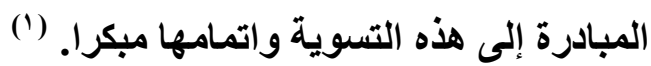

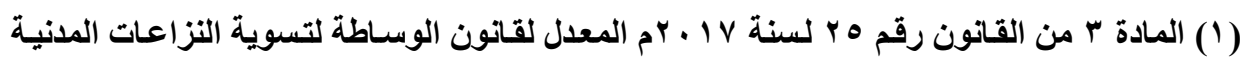

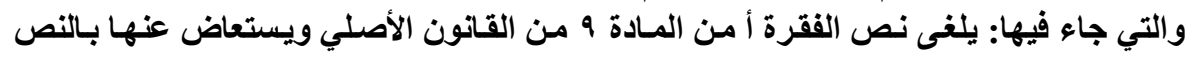
أـ إذا تمت تسوية النزاع كليا بطريق الوساطة القضائية فللخصوم:

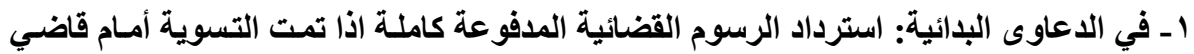
إدارة الدعوى ونصف تلك الرسوم إذا تمت التسوية بعد إحالة الدعوى إلى قاضي التئ الموضوع. $=$ 
أــ استرداد الخصوم الرسوم القضائية كاملة : - إذا أدت التسوية إلى انهاء النزاع بين خصوم الاعوى البدائية بصورة تامسة في مرحلة وجودهـا للاى قاضسي اداره اللدعوى المدنيـة فـان لمـن دفع مـن الخصوم رسـوما قضائية أن يسترد كامـل الرسوم التي دفعها، وتثبت قيمة هذه الرسوم بالوصل المسالي الذي يحصل عليه من دفع تلك الرسوم. ومن الجدير بالذكر ان مـا يدفع عن الدعوى من نفقات أو اتعاب محاماة لا علاقة له بما يتم رده لأنها لا يعد ببسـاطة من الرسوم القضائية

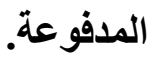
بـ استرداد الخصوم نصف الرسوم القضائية :- وفقا لنص المـادة س/أ من القانون المعدل لقـانون الوســاطة المـذكور سـابقا فـإن للخصم اسـترداد نـصف الرسـوم القضائية التي قـام بـدفعها إذا تمـت التسوية بعـد إحالـة الـدعوى إلـى قاضسي

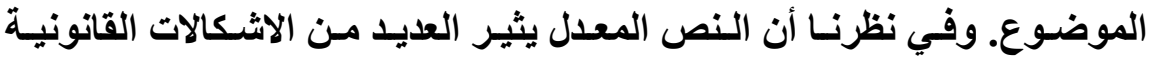
بعضها يتعلق بالدعوى الموضوعية المستعجلة وبعضها الأخر يتعلق بصلاحية قاضي الموضوع في إرجاع الدعوى بعد وصولها إليه إلى قاضي الوساطة. 1 ـ استرداد نصف الرسوم القضائية في اللاعوى الموضوعية المستعجلة : هذه الاعوى تزد إلى قاضي الموضوع مباشرة متى تحقق الشرطان المنصوص عليهمـا بالمـادة " . ؟ " مـن قانون اصـول المحاكمـات المدنية، وهمـا الشرط الإجرائي المتمثل بقرار رئيس المحكمة باعتبار هـا مستعجلة بنـاء على طلب المـدعي، والشرط الموضـوعي المتمثل باعتبار هـا مستعجلة بـنص القـانون بطبيعتها أو لأنها تقتصر على مجرد المطالبة بـدين أو مبلِغ مـالي محدد في r ـ في الدعاوى الصلحية: استرداد الرسوم القضائية المدفوعة كاملة إذا تمت التسوية قبل أن يختم

المدعي بيناته ونصف تلك الرسوم إذا تمت في أي وقت لاحق لذلك قبل صدور التهم حكم فيها. 


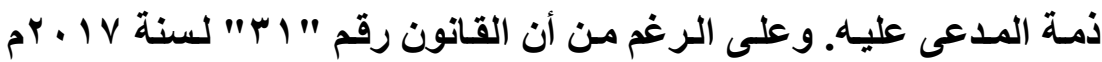
المعدل لقـانون أصـول المحاكمـات المدنية قد عدل المـادة " ـ ؟ " المــكورة وذلك بتحديد مدد لتبادل اللوائح في هذا النوع من الدعاوى بمقدار نصف

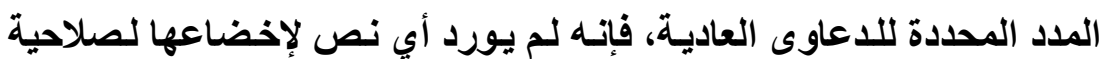
قاضــي إدارة الـدعوى المدنيـة، بـالنظر إلى صـفة الاسـتعجال التـي تقتضي عرضها على قاضي الموضوع مباشرة بعد اكتمـال تلك المدد. وقد سبق أن ذكرنا أن قاضي الموضوع لا يملك صـلاحية إحالة الدعوى التي تصله للنظر فيهـا إلى الوسـاطة القضائية أو إلى غيرهـا مـن أنواع الوسـاطة. ومـن جهـة اخـرى وفي حسال سـلمنـا جــلا بإحالتهـا لقاضـي الوسـاطة مـن قبـل قاضـي الموضسوع لتـتم التسوية بـشأنها، فـانِ اسـترداد نـصف الرسـوم القضائية المدفوعـة عنهـا لا يحقق العدالـة مقارنـة بالدعوى العاديـة التي لها فرصـة للتسوية بالوساطة القضائية قبل احالتها لقاضي الموضوع. r ـ استرداد الخصوم نصف الرسوم القضائية في اللاعوى العادية : هذه الدعوى تخضع ابتداء إلى قاضسي إدارة الدعوى وترد إلى قاضسي الموضوع مرفوعة

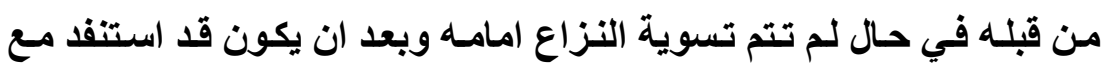
الخصوم كل فرص الحل المتاحـة بمـا فيها الوسـاطة القضائية، ومـع بقـاء تحفظنـا قائمـا على عدم صـلاحية قاضسي الموضوع وبعد ورود هذه الدعوى

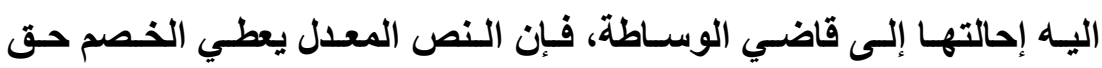
استرداد نصف الرسوم القضائية التي دفعها طالما أجريت التسوية بعد احالتها إلى قاضسي الموضوع. وقد سبقت الإشـارة إلى أن بإمكان قاضسي الموضوع وبناء على طلب الخصوم اتخـاذ القرار بوقف الدعوى ليتسنى لهم بعد ذلك اجراء مـا يرونـه مناسبا بشأن نزاعهم سـواء بالصلح أو التسوية بالوسـاطة 
الاتفاقية ولكن ليس لهم الرجوع في نزاعهم إلى قاضي ادارة الدعوى المدنية

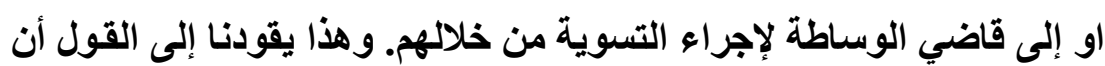

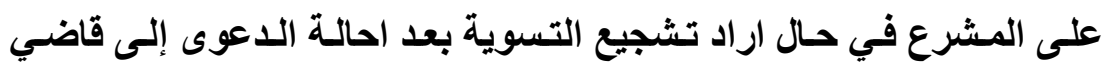

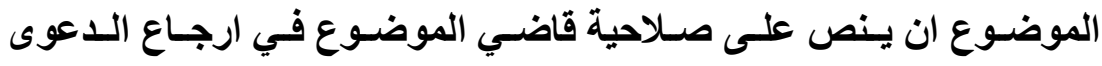

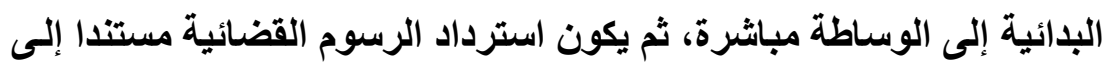

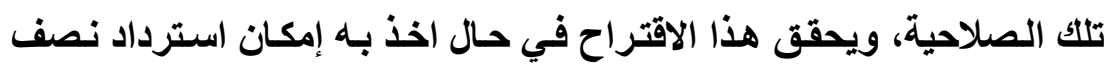

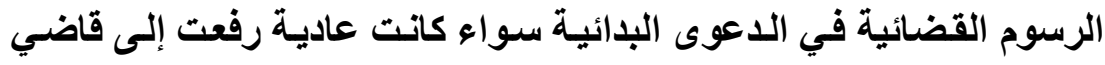

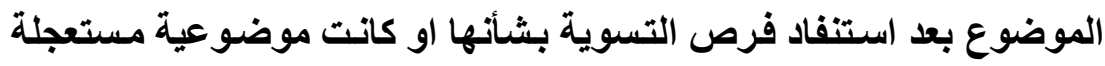

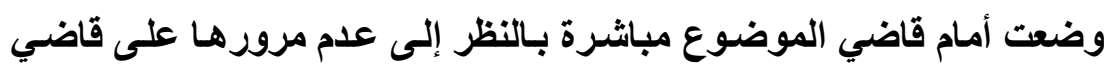

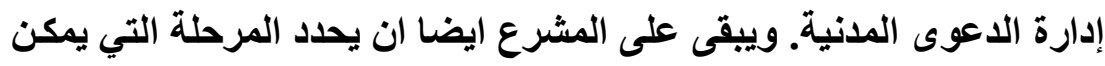

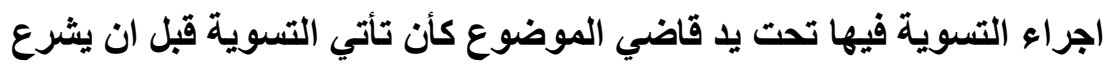
في نظرها أو قبل اختتام المدعي لبيناته حدا أقصى.

\section{الفقرة الثانية : رد الرسوم القضانية في الدعوى الصلمية}

تضمن التعديل الذي طرأ على الفقرة(أ) من المسادة "q" من قانون الوسـاطة

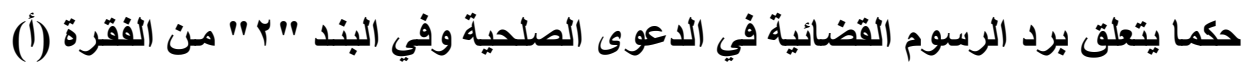

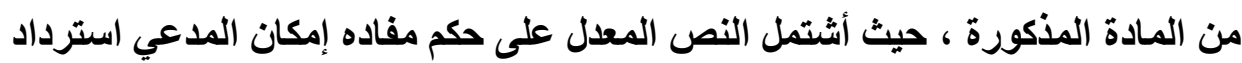
الرسوم القضائية المدفوعة في الدعوى الصلحية كاملة إذا تمت التسوية قبل ان يختنم

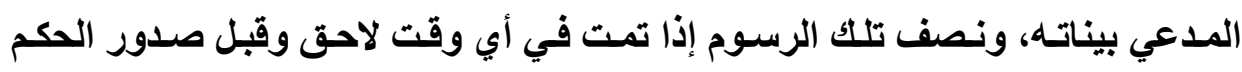
فيها'(1) وقبل أن نثرع في التعرض لهذا النص لانه بـ من الإثـارة إلى أنه أغفل تمامسا $=$ 


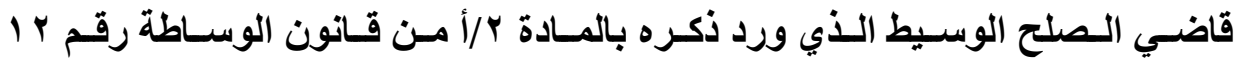

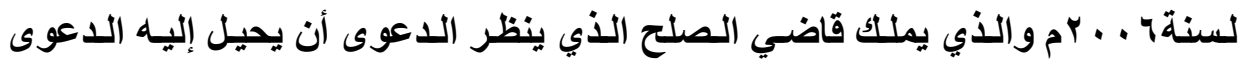
الصلحية لإجراء الوساطة بمقتضى المادة ب/أ من ذات القانون، فقي حسال أدت وسـاطته إلى تسوية تنهي النزاع فانه يرفعها إلى قاضسي الصلح الذي ينظر موضوع الدعوى، ففي هذه الحالة وهي الحالة الواقعية الممكنة التي تتحقى فيها حكمة انهاء النزاع قبل نظره من قبل قاضي الموضوع لا نرى ذكرا لحق المدعي في استرداد الرسوم القضائية التي دفعها وقد اقتصر نص البند ب/أ من المادة التاسعة على ذكر حالتين لرد الرسوم على النحو التالي :- - ع

أـ رد رسوم الدعوى الصلحية كاملة للمدعي في حال تمت التسوية القضائية قبل ان يختم بيناته :- إن إجراء تسوية للنزاع بتمامه امام قاضي الصلح الوسبط ورفعه إلى قاضي الصلح يتم استيعابه من هذه الحالة اذ يعتبر أنه تم قبل اختتام المدعي بياناته، بل إنه تم قبل الثروع في نظر الدعوى أساسـا، وعليه يمكن رد الرسوم القضائية كاملة للمدعي في هذه الحالة. لكن في حال رفعت الدعوى الصلحية من قبل قاضسي الصلح الوسبط بعد فشل الوسـاطة ، إلى قاضسي الموضوع فبإن هذا الاخير لا يملك حق اجراء الوسـاطة القضائية بنفسه ولا حتى حق اعادتها إلى قاضي الصلح الوسيط، وما يملكه فقط هو عرض الصلح على الخصوم وفق نص

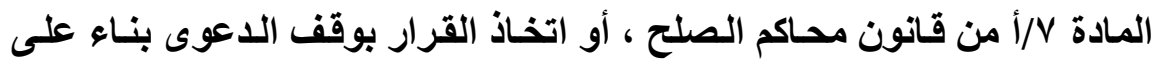

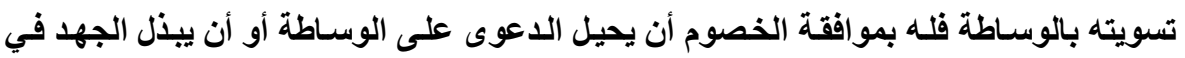

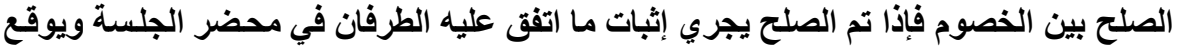

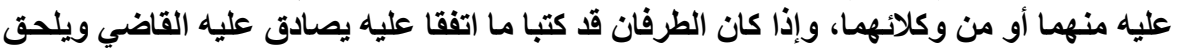

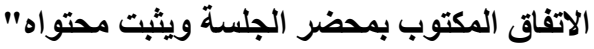


طلب الخصوم لتسويته اتفاقيا على النحو الذي أسلفنا(' ) وعليه لا يمكن تصور إجراء الوسـاطة القضائية بعـ أن يشرع قاضسي الموضسوع الصلحي في نظر

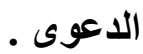

بـ رد نصف رسوم الدعوى الصلحية إذا تمت التسوية القضائية بعد اختتام المدعي

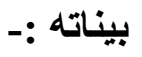

هذه الحالـة مماثلــة لمـا سـبقتها في النتيجـة إذا لا يتصور إجـراء التسوية في اللدعوى الصلحية بالوسـاطة القضائية من بـاب اولى في مرحله متقدمسة على مرحلة اختتام المدعي بيناته فليس له سوى تثبيت الصلح الذي يمكن ان يصل اليه الخصوم في الاعوى سندا لنص المـادة "V" من قانون محساكم الصلح التي سبقت الإشـارة اليها. ولكي يحقق المشرع الحكمة من فض النزاع الصلحي بالتسوية القضائية فان عليه اعادة صياغة البند ب/أ من المادة 9 من قانون الوساطة على ان تتضمن هذه الصياغة

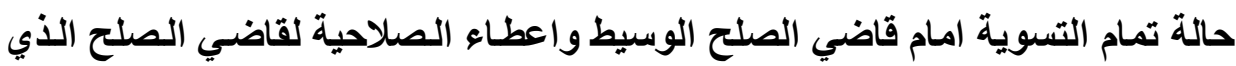
ينظر النزاع ارجاع او إحالة النزاع إلى قاضي الصلح الوسيط.

\section{الفرع الثاني : رد الرسوم نتيجة الوساطة غير القضانية}

تكفلت الفقرة ب من المادة " ه" من قانون الوسـاطة بتظيم احكام رد الرسوم في حالة اجراء التسوية من خلال الوسيط الخاص وكذلك المـادة سّ/ب من ذات القانون في حاله اجراء التسوية من خلال الوسيط الاتفاقي، علما بان هذين النصين لم يشملهما التعديل بموجب القانون رقم "ه Y " لسنة V V ـ Yم، فكانا بالتـالي بمنـأى عن الاشكالات التي حدثت بسبب تعديل الفقرة "أ" من المادة "q" من القانون الاصلي. 


\section{الفقرة الأولى : رد الرسوم في حال اجريت التسوية هن قبل الوسيط الخاص}

إذا نجحت وساطة الوسيط الخاص وتوصل إلى تسوية النزاع كليا في اللاعوى المدنية سواء كانت بدائية أم صلحية فإن للمدعي حق استرداد نصف الرسوم القضائية التي دفعها وذلكك بصريح نص البند //ب من المادة " q" من قانون الوسـاطة. ولم يرد

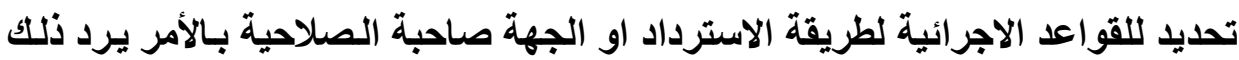

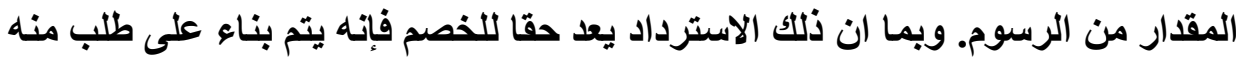
يقدم باستدعاء خاص يرفق به التصديق على اتفاقيه التسوية المنهية للنزاع، أما الجهة

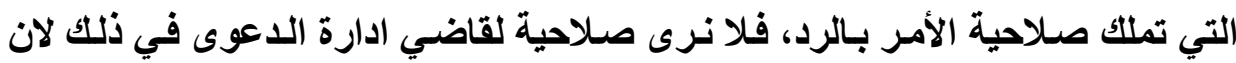

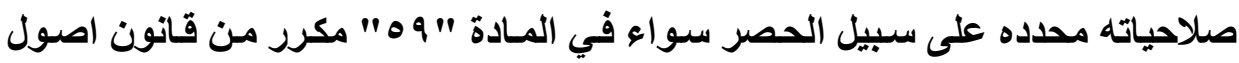
المحاكمات او في نصوص قانون الوساطة. وبالنظر إلى ان قاضي الموضوع هو الذي

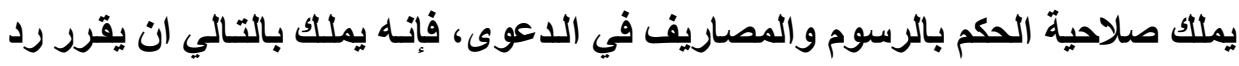
ما يستحق من الرسوم القضائية لمن دفعها. وتجدر الإثارة إلى ان القانون قد اشترط لاستحقاق رد نصف الرسوم بناء على

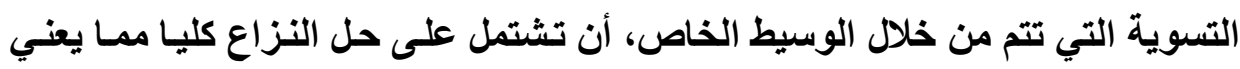
انه لو نجحت هذه الوساطة بحل جزء من النزاع لم يكن من حق في الاسترداد. الفقرة الثانية : رد الرسوم في حال اجريت الوساطة هن قبل الوسيط الاتفاقي نصت على حكم هذه الحالة المـادة "ب/ب" من قانون الوسـاطة حيث تضمنت انـه في حال تمت تسوية النزاع وديا عن طريق الوسيط الذي اتفق عليه الطرفان،

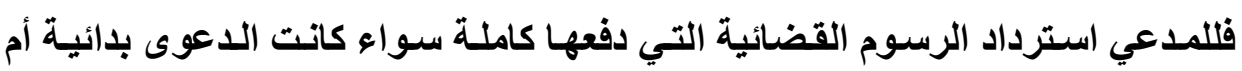
صلحية. 


\section{الاطلب الثاني \\ اتعاب الوسطاء}

يحتاج الوسيط الأي يتذخل بين طرفي الخصومة لتسويتها رضـائيا فيما بينهم إلى جهود ومساع منه تجاه كل واحد منهم وذلك لترسيخ القناعة لايهم في الوصول إلى حل مرض لهم جميعا. وعليه فان هذه مهمة قد تكون شـاقة بعض الشيء وهي عبارة عن عمل يقوم بـه الوسيط في الدعوى المدنية من اجل الوصول إلى تسوية ينتهي بمقتضاها النزاع بين الخصوم. ويستحق الوسيط اتعابا معينة عن هذا العمل في حال قام بتنفيذ مهمته بنجـاح، وذلك تشجيعا لـه من ناحيـة على أداء هذه المهمة وبـذل كافة الجهود الممكنة تجاه الأطراف ووفاء للأجر الذي يستحقه مقابل ذلك العمل الذي اداه

$$
\text { من ناحية أخرى. }
$$

\section{الفرع الأول: هقدار أتعاب الوسيط}

نظم قانون الوساطة المدنية أتعاب الوسطاء ومقدارها واستحقاقها بالنسبة لكل

شكل من اشكال الوساطة وانواع الوسطاء وذلك على التحو التالي:

$$
\text { الفقرة الاولى : هقدار اتعاب الوسيط الاتفاقي }
$$

تتضمن الفقرة ب من المادة "ب" من قانون الوساطة ان الوسيط الاتفاقي تحدد

$$
\text { اتعابه بالاتفاق مع أطراف النزاع(' . . }
$$

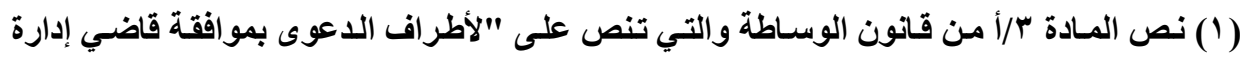

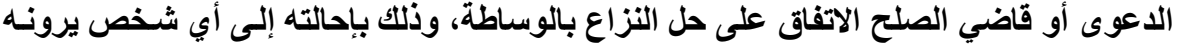

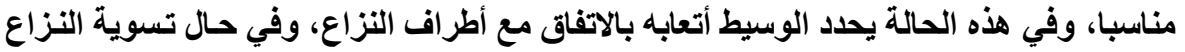
وديا يسترد المدعي الرسوم القضائية التي دفعها. 
ويفهم مسن ذلك أن اتعـاب هذا الوسبط محكومسة بالعقد الذي يبرم بينـه وبـين أطراف النزاع، ويخضع هذا العقد للقواعد العامـة للعقود ولغايـات صـحة ابرامـه ولـم يشترط القانون الكتابة لانعقاده مما يجعل الكتابة فيه شرطا للإثبات فقط ووفقـا لقواعد

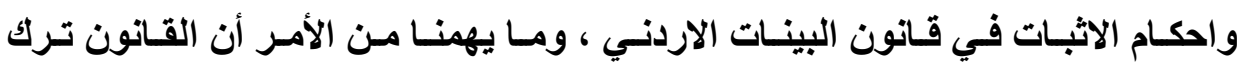
للأطراف في اتفاقية الاتعاب وهم الوسيط من ناحية وفرقاء النزاع المدني من ناحية

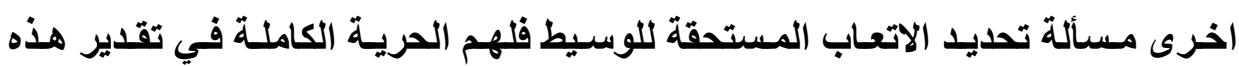
الاتعاب برضاهم استنادا إلى ان العقد شريعة المتعاقدين لكنتا نعتقد ان هذه الاتعاب في مقدارها لابد ان تتناسب مع قيمة الدعوى المدنية التي يتم التوسط في شـأنها، كمـا ان القـانون لـم يـص في هذا النـوع من الوسـاطة لغايـات استحقاق الأتعاب نجـاح جهود الوسيط في الوصول إلى تسوية كاملة للنزاع كل ما هنالك انه ربط فقط مسألة استرداد اد

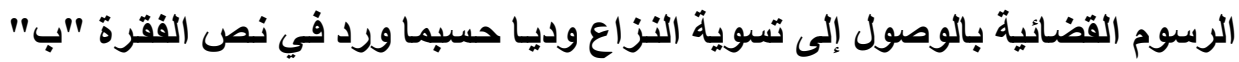
من المـادة "ب" المشار إليهـا سـابقا. وعليه يمكن القول إن أطراف اتفاقيـة الأتعـاب يستطيعون تحديل مقار الأتعاب التي يستحقها الوسيط الاتفاقي في حال نجاحه كليا او جزئيا في الوصول إلى تسوية او حتى فشله في ذلك برغم جهوده المبذولة من قبله

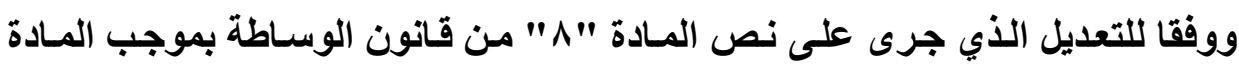

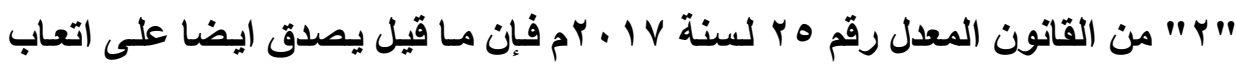
الوسيط الاتفاقي الذي يجري وسـاطته بالاتفـق مـع أطراف النزاع المدني. قبل اقامـة

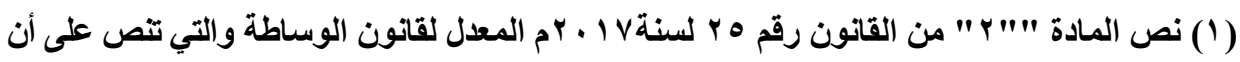

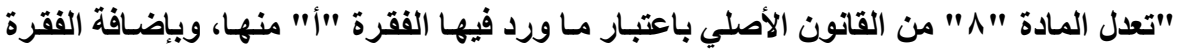

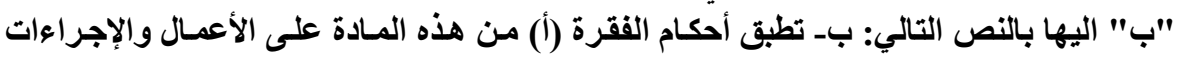

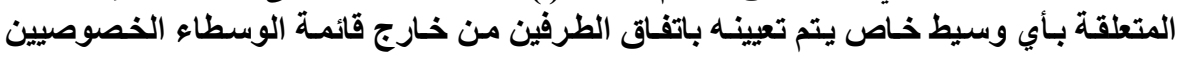

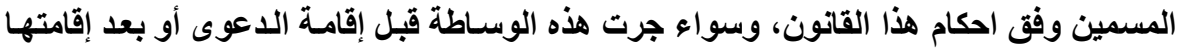




\section{الفقرة الثانية : هقدار اتعاب الوسيط الخاص}

وفقا لأحكام الفقرة "ب" من المسادة التاسعة من قـانون الوسـاطة فـان اتعـاب الوسيط الخاص تقدر بناء على نجاحه في حل النزاع وذلك على النحو التالي:

\section{أ- هقدار أنعاب الوسيط الخاص في حال نجاحه بالوصول إلى تسوية النزاع كليا:}

تحدد اتعاب الوسيط الخاص في حال نجاحه بتسوية النزاع كليا بمقدار نصف الرسوم القضائية للاعوى، فاذا كان هذا النصف اقل من ثلاثمائة دينـار تم اتمامـه إليها

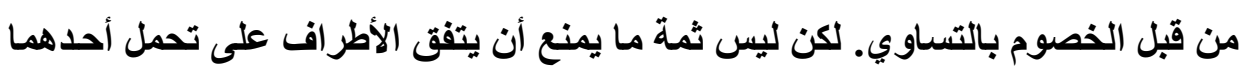
هذه الأتعاب دون الأخر لأن النص المذكور يتضمن قاعدة قانونية غير آمرة وبالتالي لإني يمكن لهم الاتفاق على خلافها.

\section{ب- مقدار اتعاب الوسيط الخاص في حال عدم نجاحه بتسوية النزاع :}

وفقا للبند "ץ" من الفقرة ب من المادة "q" من قانون الوساطة. فِان الوسيط

الخاص في حال عدم وصوله إلى تسوية النزاع او انهه توصل إلى تسوية لكن بصوره

جزئية فإن اتعابه عن الدعوى المدنية صلحية كانت ام بدائية تحدد من قبل قاضي ادارة الدعوى على الا تتجاوز في حدها الأعلى مبلغ مائتي دينار، يلتزم المداعي بدفعها لـه وتعتبر من ضمن مصاريف ونفقات الدعوى، وبما أن قاضي إدارة الدعوى مسؤول فقط

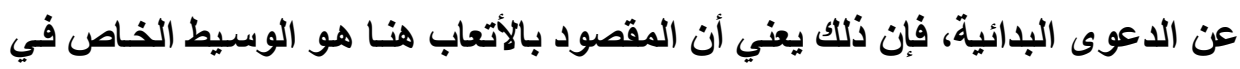

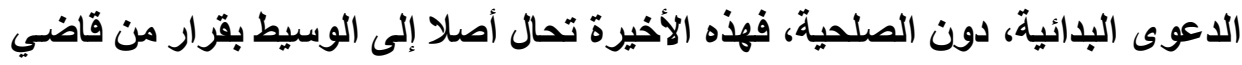

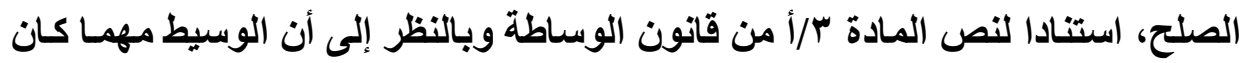

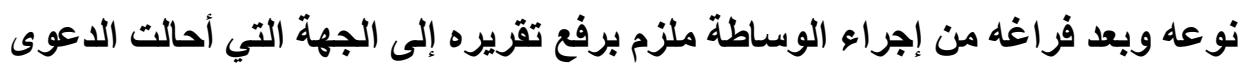

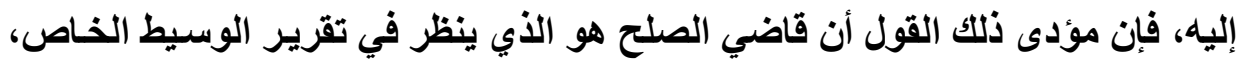

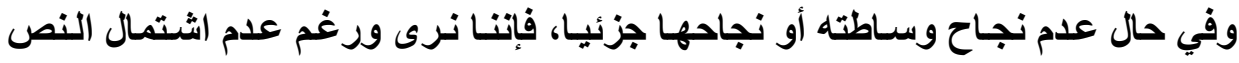


على ذللك أن يحدد أتعاب الوسيط الخاص، بما لا يتجاوز المقدار الوارد بالمـادة 9/ب/ ؟ من قانون الوساطة، استنادا إلى أن قاضي الموضوع مسؤول عن اللدعوى وعن اتخاذ أية قرارات إعدادية أو ذات صلة بها، وتجدر الملاحظة أن البند "ץ" المذكور يتضمن قاعدة آمرة ـ فـلا يجـوز بـأي حسال مخالقته بتحديــ مقدار أتعـاب الوسيط الخـاص بمـا يتجاوز المائتي دينار. كما يمكن ملاحظة الفرق في أتعاب الوسيط الخاص الاتفاقي التي تحدد باتفاقه مع أطراف النزاع، وأتعاب الوسيط الخـاص الوارد ضمن قائمسة الوسطاء الخصوصيين والتي لا تتجاوز المائتي دينار في الحالة التي نحن بصددها. ونعتقد أنه من الملائم أن يترك القـانون للوسيط الخـاص الاتفـاق مـع الأطراف على تحديد أتعابه فِان كاتت أكثر من نصف الرسوم القضائية المدفوعة، أكملت من أطر اف النزاع. ولعل في ذلك تحقيقا للمساواة بين الوسيط الاتفاقي والوسيط الخـاص حسب قائمة الوسطاء من ناحية، واعتبار مسألة الاتعاب ذات طبيعة اتفاقية من ناحية ثانية، وهي مرتبطة بموضوع الدعوى ومقدارها والجهود المبذولة من الوسيط في تسويتها أو تسوية جزء منها من ناحية ثنالثة.

\section{الفرع الثاني : عدم استمقاق الاتعاب}

إن عدم استحقاق أية اتعاب عن اعمال الوساطة وجهود الوسطاء إمـا ان يكون مرده شكل الوسـاطة ونـوع الوسيط أو أن يرجع إلى فشل الوسبيط في الوصول إلى إسى تسوية بخطئه وتقصيره.

الفقرة الأولى : عدم استحقاق الوسيط القضائي أية أتعاب عن وساطته بالنظر إلى ان الوسيط القضائي في الاصل هو أحد قضاة البداية أو الصلح والذي تتم تسميته من قبل رئيس محكمه البدايـة وفقـا لنص المـادة ب/أ من قانون الوسـاطة

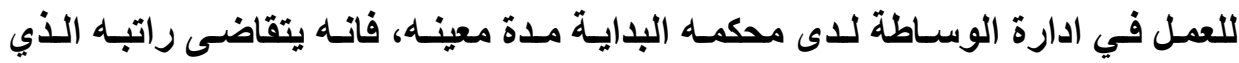


يستحقه بصفته قاضيا وفقا لرتبته ودرجته وحسب نظام الرواتب الخـاص بـه، وعمله قاضيا للوساطة ما هو الا تكليف بهذه المهمة فيقوم بها طيلة مدة تكليفه من قبل رئيس وديس محكمة البالية ولا يستحق عن اداء مهامه هذه اية اتعاب عن اعمال وسـاطته باعتبارهـا جزأ من مهامه الوظيفية.

الفقرة الثانية : عدم استحقاق الوسيط أيسة أتعـاب بسبب فشله في الوصسول إلى تسمية النرناع

لا نقصد هنا فشل الوسيط في الوصول إلى تسوية النزاع المدني الذي يكون

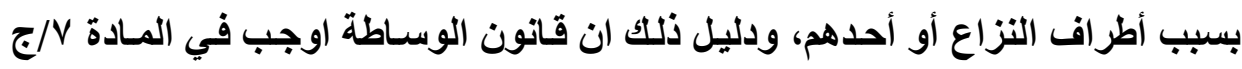

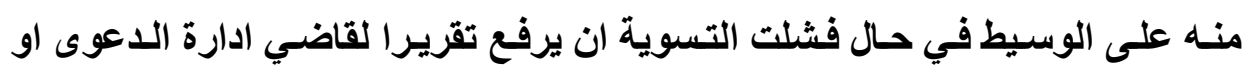

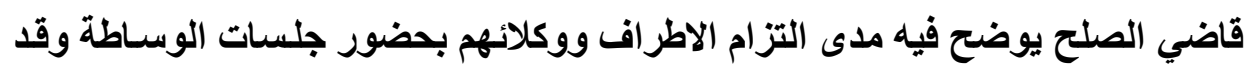

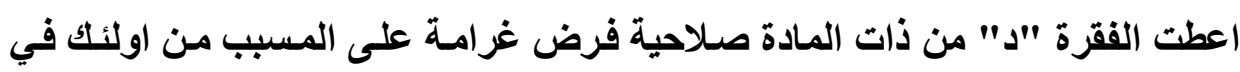
إفثشال اعمال التسوية.

لكنتا نقصد ان يكون فثل التسوية راجعا إلى اهمال وتقصير من الوسيط وعدم

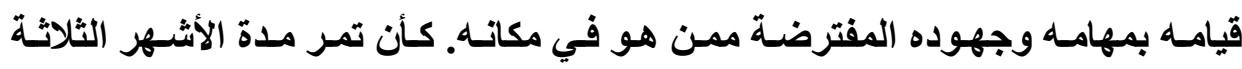
المحددة له بالمادة V/أ لإنهاء اعمال الوساطة دون ان ينجز أيا من هذه الاعمـال أو ان

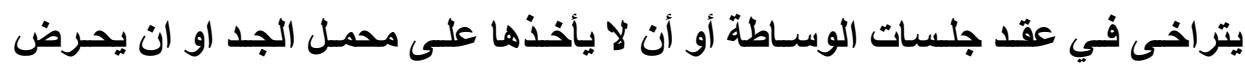

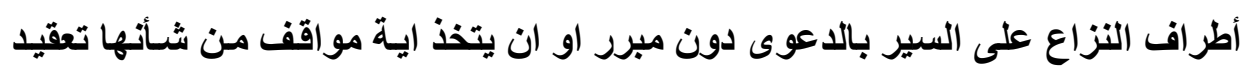

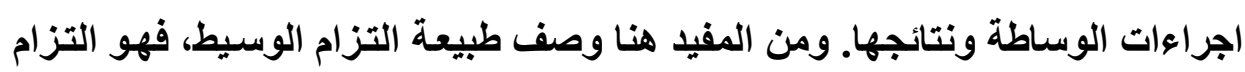

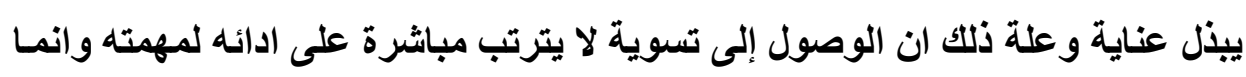
يرتبط برضا أطراف النزاع ووصولهم إلى حل ودي تثاركي منهم. 
ويؤكد سـلامة هذا الاسـتتـاج ان القـانون في المـادة و/ج مـن قـانون الوسـاطة اعطى لقاضي إدارة الدعوى تحديد صلاحية اتعاب الوسيط حتى في حال عدم الوصول إلى تسوية للنزاع. ولو كان التزامه بتحقيق نتيجة لمـا كـان لله حق في ايـة اتعـاب مـالم تتحقق التسوية بفضل جهود الوساطة.

إذن الوسيط الخاص، أو الوسبط الخـاص الاتفاقي، يستحق اتعابـا عن جهوده المبذولة في اعمال الوساطة سواء تحققت النتيجة وهي اتفاقية التسوية ام لا، وتنتفي احقيـة الوسـيط لأيـة اتعـاب إذا فشلت الوسـاطة بسبب تقصيره و إهمالـه وعدم قيامسه بالجهود التي يمكن ان تسفر عن تسوية النزاع. ويستطيع أطراف النزاع او الطرف الأي يقع عليه الالتزام بأداء اتعاب الوسيط ان يدفع بعدم تنفيذ الوسيط لالتزامه، بل وأن

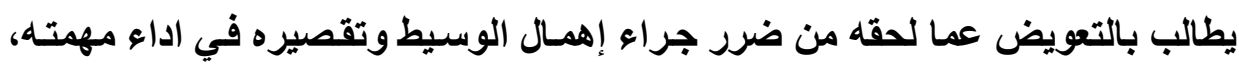
وفقا للقواعد العامة في القانون . 


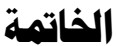

على الرغم من ان الوسـاطة باعتبارهـا واحدة من السبل البديلة لحل وتسوية

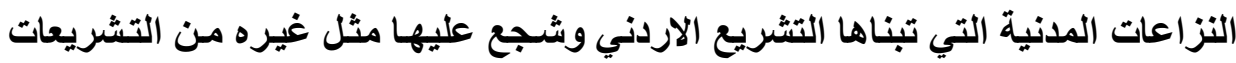

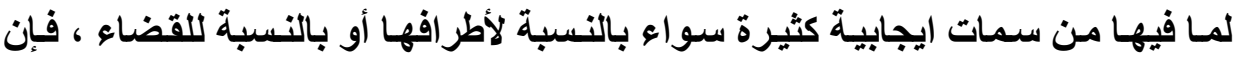
نجاحها رهين بارادة الخصوم في النزاع المدني ـ

وقد توصلنا في نهاية هذا البحث إلى عدة نتائج نذكر منها ما يلي: ا ـ توافق الأطراف على الوسيط أيا كان يعد أمرا لازما لإنجاح مساعيه في الوصول

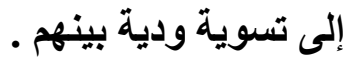
r- تعريف الوسـاطة بانها وسيلة اختيارية لأطراف النزاع المدني سواء من حيث اللجوء اليها او من حيث الوسيط القائم عليها او من حيث التسوية الناتجة عنها. r- تبنى المشرع الأردني نوعا جديدا للوساطة وهو الوساطة السابقة على الدعوى المدنية فإذا نجم عنها تسوية اعتبر صلحا يستوجب اركان عقد الصلح وشرائطه

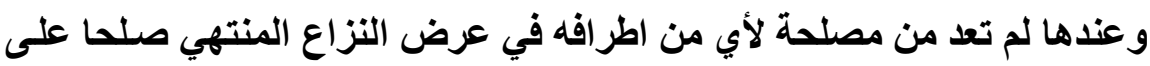
القضاء. צ- ـلجوء الخصم إلى رفع دعوى بشأن نزاع مدني اتفق على طله وديا يجعل من الدعوى سابقة لأوانها وترد اذا تمسك المدعى عليه بعدم استنفاد المدعي فرصته

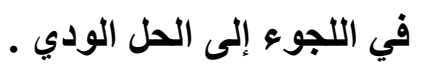

هـ لا يملك قاضي الموضوع صلاحية إحالة النزاع إلى الوسـاطة بعد وصول النزاع

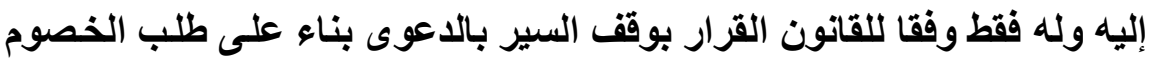
ولهؤلاء عندئذ إحالة نزاعهم إلى وسيط اتفاقي لحله. 
צـ تصديق قاضي ادارة الدعوى المدنية على اتفاقية التسوية الناجمة عن جهوده مع الخصوم يجعل منها بمثابة حكم قضائي مما يجعل منها قابلة للطعن شأنها في ذلك شأن الحكم القضائي ، في حين أن التصديق على اتفاقية التسوية الناجمـة عن جهود الوسيط يجعل منها بمثابه حكم قضائي قطعي .

V- الدعوى المدنية التي تقبل الوساطة هي التي يكون موضوع النزاع فيها ماليا. A- الدعوى المدنية الموضوعية التي تنظر على صفة الاستعجال لا تحال إلى قاضسي ادارة الدعوى ولا تتحقق فيها بالتالي فرصة رد الرسوم كاملة. 9- مقدار اتعـاب الوسـيط الخـاص محددة بنص قـانون الوسـاطة لتسوية النزاعـات المدنيـة ، في حين أن مقدار اتعـاب الوسـيط الاتفـاقي غير محددة بموجبـه ، وبالتالي فإن امر تحديدها يرجع إلى اتفـاق الخصوم مـع الوسيط الاتفـي وهذا يؤدي إلى تباين في مقدار اتعاب الوسيط الخاص والوسيط الاتفاقي . • 1 ـيعد التزام الوسيط بالوصول إلى تسوية بين الخصوم التزامـا يبذل بعنايـة ، فاذا

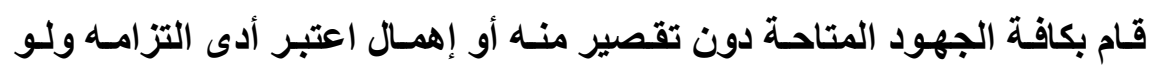
فثلت الوساطة ، ولا يحرم الوسيط الخاص من الاتعاب الا اذا كان الفشل راجعا إلى اهماله أو تقصيره . أما اهم التوصيات التي نرى ضرورة تعديل القانون للأخذ بها حرصـا على ثمـار الوساطة وتحقيقا لأهدافها وغاياتها فهي الواردة تاليا : 1- تعديل المادة "ب/أ" من قانون الوساطة بإلغاء عبارة (مراعاة موافقة الخصوم مـا

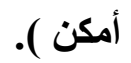


r- توحيد الحكم في القانون بالنسبة لاتفاقية التسوية الناجمة عن جهود الوسيط وتلكك الناجمة عن جهود قاضي إدارة اللدعوى وذلك بتعديل المسادة وه مكرر من قانون اصول المحاكمات المدنية ، فتكون أي منهما بالتالي بمثابة حكم قضائي قطعي في

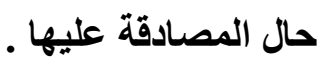

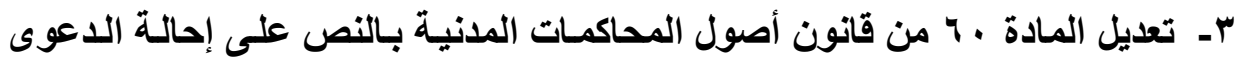
الموضسوعية المستعجلة لقاضسي إدارة الـدعوى ضــن مـددها الخاصـة بتبـادل اللوائح . ـ - ترك امر تحديد اتعاب الوسيط الخـاص لاتفاقهه مـع الخصوم ، تحقيقا للعدالة بين الوسيط الخاص والوسيط الاتفـاقي ولضمان انسجام الاحكام القانونية ذات الصلة بموضوع واحد.

هـ على المشرع وضـع نـص جليــ في قـانون الوسـاطة يعطي الـصلاحية لقاضسي الموضوع بإحالـة اللدعوى إلى الوسـاطة ، ليشكل بذلك اساسـا قانونيا تبنى عليه النصوص القانونية المتعلقة باسترداد الرسوم القضائية . فالنص المقترح يعد أصلا تقوم عليه النصوص المذكورة باعتبار ها فروعا ، وبذلك تتحقق غايـة المشرع مـن التعديل الذي طرأ على النصوص القانونيـة الناظمـة

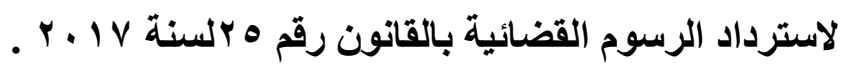

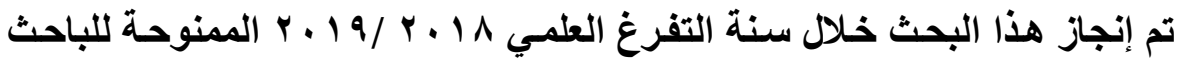
من جامعة ال البيت 


\section{قائمة المراجع والمادر}

\section{أولا : المراجع}

ا - عباس العبودي شرح احكام قـانون اصول المحاكمـات المدينـة دار الثقافة للنشر

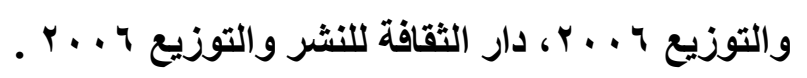

r- مفلتح عواد القضاة، اصول المحاكمـات المدنيـة والتنظيم القضائي، دار الثقافة

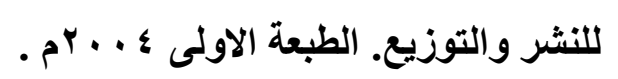

r- محمد نصر الرواشدة، ادارة الدعوى المدنية في النظام القضائي، دراسـة مقارنـه

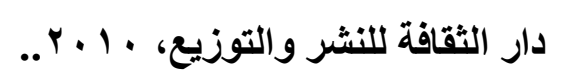

ـ- جـلال وفـاء محمـدين، تـسوية منـازعـات التجـارة الدوليـة فـي إطــار اتفاقيـات

$$
\text { الجات r . . . Fم، دار الجامعة الجديدة للنشر. }
$$

هـ شـادي حلـو عبد الرحمن أبو حلو، تسوية منازعـات الاستثمار الأجنبي، وفقا

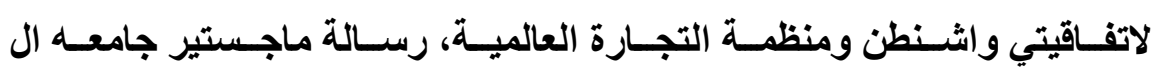

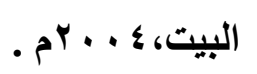

ד- شـبكة قـانوني الأردن أحمـــ ابـوزنط وآخـرون، القـانون المــني الأردنسي رقـم

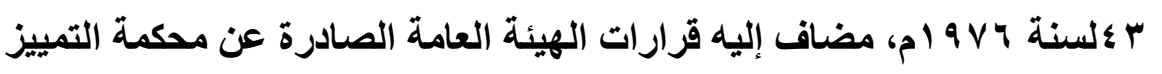
إضـافة إلى مقتطفـات نوعيـة مـن المـكرة الايضاحية للقـانون المدني، دار وائلـ

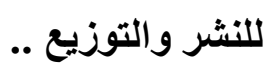

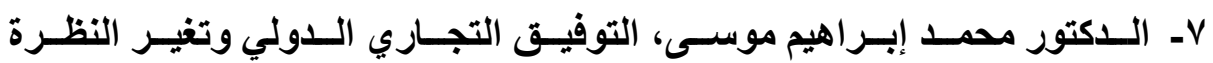

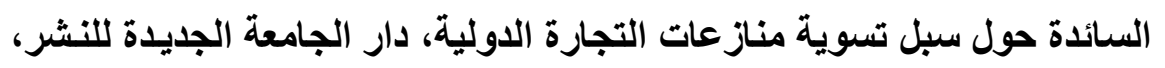

$$
\text { . } . \text {. O }
$$




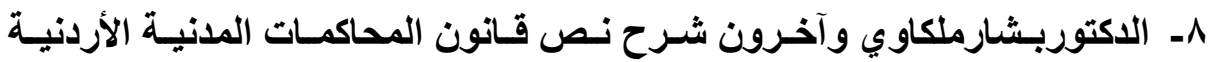
، الطبعة الأولى ، . . . r م،داروائل للنشر.

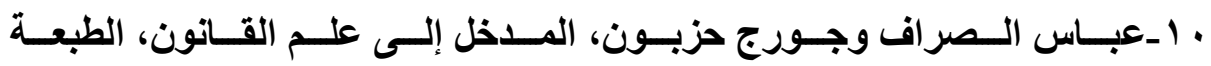

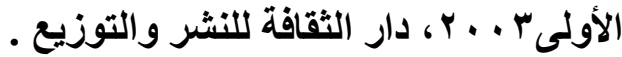

9- معتز محمد حوامدة، الدوفوع الشكلية في الدعوى المدنية،، رسـالة ماجستير،

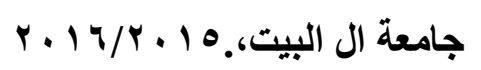

• اـمنـى عـادل طـه، الوسـائل غير القضائية في تسوية منازعات العقود الإداريـة، دراسة مقارنة، رسالة ماجستير ه 1 ـ ب ، جامعة ال البيت .

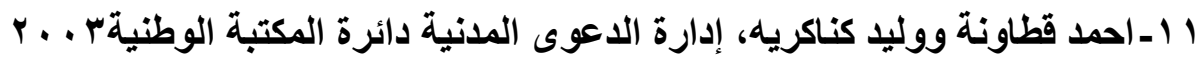
r ا ـ عبدالقادر الفار، مصادر الالتزام، مصادر الحق الشخصي في القانون المدني -

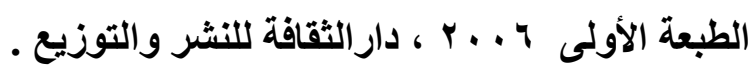

ب ا ـ الـاكتور مفلح عواد القضاة، أصسول المحاكمـات المدنيـة والتظظيم القضائي ،

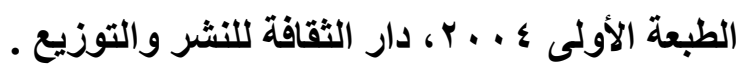

https://www.law-arab.com/2016/11/lawsuitdefinition - I $r \cdot 19 / 1 / r r$

\section{ثانيا : الامسادر}

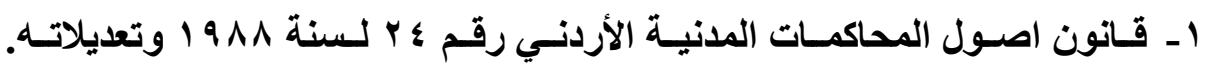

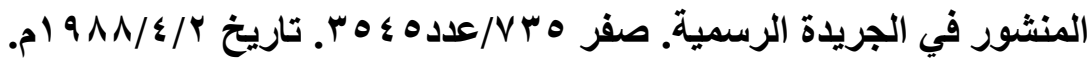
r ـ القانون المعدل لقانون اصول المحاكمات المدنية رقم اس لسنة V V ـ ب المنشور

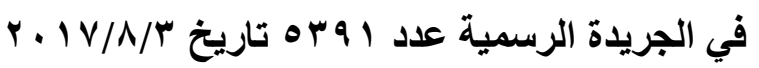




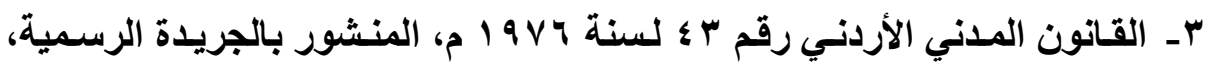

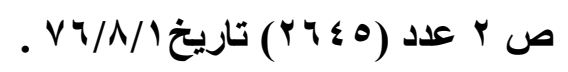

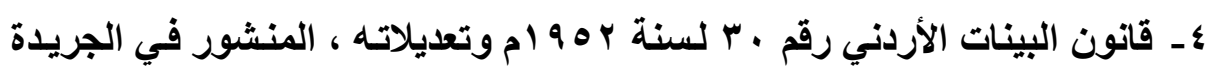

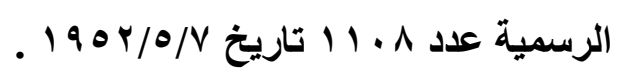

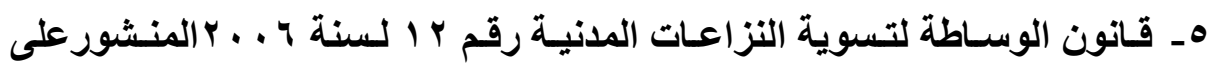

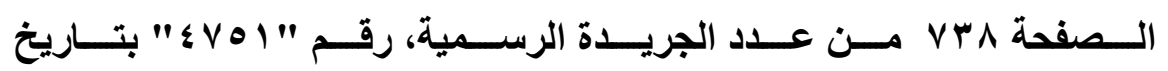

$$
\text { . } . \cdot T / \Gamma / 1 T
$$

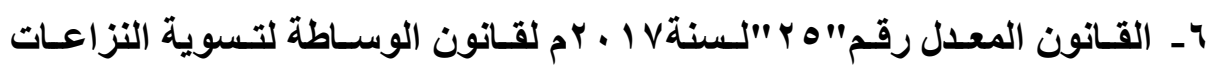

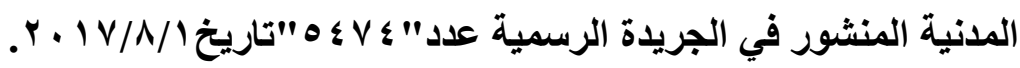

V- قانون الجنسية الأردني رقم 1 لسنة ؛ه 9 ام والمنشور في الجريدة الرسمية رقم

$$
\text { ا } 11 \mathrm{VI}
$$

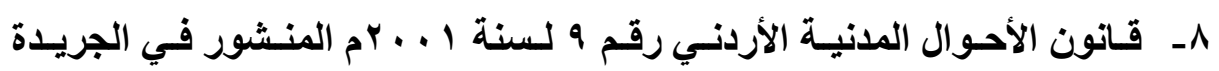

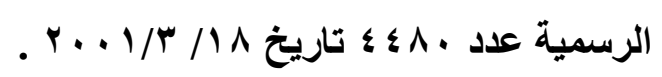

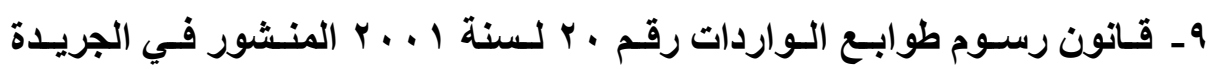

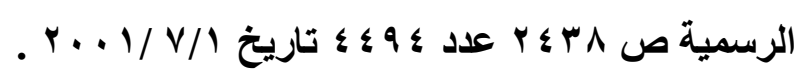

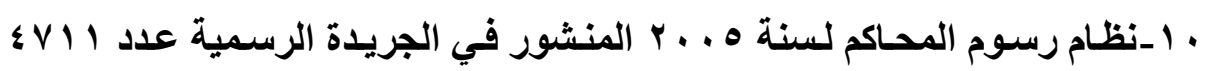

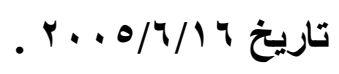

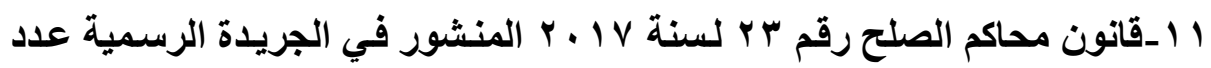

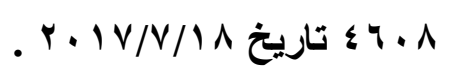

